NBER WORKING PAPER SERIES

\title{
OFFSHORE PROFIT SHIFTING AND AGGREGATE MEASUREMENT: BALANCE OF PAYMENTS, FOREIGN INVESTMENT, PRODUCTIVITY, AND THE LABOR SHARE
}

\author{
Fatih Guvenen \\ Raymond J. Mataloni, Jr. \\ Dylan G. Rassier \\ Kim J. Ruhl \\ Working Paper 23324 \\ http://www.nber.org/papers/w23324

\begin{abstract}
NATIONAL BUREAU OF ECONOMIC RESEARCH
1050 Massachusetts Avenue

Cambridge, MA 02138
\end{abstract} \\ April 2017, Revised February 2022
}

Date: January 2022. First version: June 2016. An earlier version circulated under the title "Offshore Profit Shifting and Domestic Productivity Measurement." We are particularly grateful to our three anonymous referees and the editor for comments that transformed this paper for the better. We thank Jennifer K. Bruner and Alberto G. Ramon for their assistance with the statistical analysis. For comments and suggestions, we thank Pol Antras, Alan Auerbach, Nick Bloom, Jennifer Blouin, Kimberly Clausing, Carol Corrado, Arnaud Costinot, Jason Furman, John Fernald, Sebnem Kalemli-Ozcan, Mitchell Petersen, Leslie Robinson, and especially our formal discussants Stefania Garetto, Molly Saunders-Scott, and Dan Sichel. The statistical analysis of firm-level data on U.S. multinational companies and companies engaged in international transactions was conducted at the Bureau of Economic Analysis, U.S. Department of Commerce, under arrangements that maintain legal confidentiality requirements. The views expressed in this paper are solely those of the authors and not necessarily those of the U.S. Department of Commerce, the Bureau of Economic Analysis, the Federal Reserve Bank of Minneapolis, the Federal Reserve System, or the National Bureau of Economic Research.

NBER working papers are circulated for discussion and comment purposes. They have not been peer-reviewed or been subject to the review by the NBER Board of Directors that accompanies official NBER publications.

(C) 2017 by Fatih Guvenen, Raymond J. Mataloni, Jr., Dylan G. Rassier, and Kim J. Ruhl. All rights reserved. Short sections of text, not to exceed two paragraphs, may be quoted without explicit permission provided that full credit, including $\odot$ notice, is given to the source. 
Offshore Profit Shifting and Aggregate Measurement: Balance of Payments, Foreign Investment, Productivity, and the Labor Share

Fatih Guvenen, Raymond J. Mataloni, Jr., Dylan G. Rassier, and Kim J. Ruhl

NBER Working Paper No. 23324

April 2017, Revised February 2022

JEL No. E01,E24,F23,O4

\section{ABSTRACT}

We show how offshore profit shifting by U.S. multinational enterprises affects several key measures of the U.S. economy. Profits shifted out of the United States grew rapidly from the mid-1990s to 2010 and have since waned. From 1982-2016, on average, 38 percent of income attributed to U.S. direct investment abroad is reattributable to the United States. We find that adjusting for profit shifting shrinks the trade deficit, decreases the return on U.S. foreign direct investment abroad, boosts productivity growth rates in the late 1990s and early 2000s, and lowers labor's share of income.

Fatih Guvenen

Department of Economics

University of Minnesota

4-101 Hanson Hall

1925 Fourth Street South

Minneapolis, MN, 55455

and NBER

guvenen@umn.edu

Raymond J. Mataloni, Jr. Bureau of Economic Analysis 4600 Silver Hill Road Washington, DC 20233 raymond.mataloni@bea.gov
Dylan G. Rassier

Bureau of Economic Analysis

4600 Silver Hill Road

Washington, DC 20233

dylan.rassier@bea.gov

Kim J. Ruhl

Department of Economics University of Wisconsin-Madison 7444 Social Science Building 1180 Observatory Drive Madison, WI 53706

and NBER

ruhl2@wisc.edu 


\section{Introduction}

In this paper, we study the implications for aggregate measurement of offshore profit shifting by domestic and foreign multinational enterprises (MNEs) operating in the United States. Offshore profit shifting (for brevity, "profit shifting") occurs when an MNE structures itself so that profits that would have accrued in the United States accrue instead in its foreign affiliates. These shifted profits are recorded in the U.S. primary income account as a return on U.S. assets held abroad, which is not counted in U.S. GDP. ${ }^{1}$ Using firm-level data, we show that profit shifting has reduced U.S. GDP as measured in official statistics. Over the years 1982-2016, we estimate that, on average, 38 percent of income recorded by U.S. MNEs on their foreign direct investment should be reattributed to U.S. GDP. We find that profit shifting is concentrated in industries and firms with significant research and development spending, providing support for the theory that intangible assets facilitate profit shifting.

Profit shifting was not a significant factor in the U.S. economy until the late 1990s, when both income on U.S. foreign direct investment and profit shifting accelerated. Our estimates of shifted profits peak in 2010 at almost $\$ 200$ billion and have since averaged about $\$ 150$ billion per year. To explain the contribution of profit shifting to U.S. economic measurement, we begin with two important facts.

First, the total economic activity generated by U.S. MNEs is very large and has grown significantly in the past 20 years. The total global value added of U.S. MNEs was $\$ 5.22$ trillion in 2016, making them equivalent to the fourth-largest economy in the world, trailing only the United States, the European Union, and China. In the same year, their domestic value added was $\$ 3.92$ trillion, accounting for 27.6 percent of U.S. business-sector value added. Furthermore, in the last 20 years, U.S. MNEs have substantially increased their global operations: earnings on U.S. direct investment abroad (USDIA) averaged 15.2 percent of corporate profits from 1982 to 1993 but grew to 27.3 percent (\$441 billion) of corporate profits in $2016 .^{2}$

Second, MNEs own significant stocks of intangible capital (e.g., intellectual property, brands, blueprints) and have a presence in countries that vary widely in corporate tax rates. These characteristics allow MNEs to legally take advantage of differences in national tax regimes to shift profits from high-tax jurisdictions - such as the United States - to low-

\footnotetext{
${ }^{1}$ This is the appropriate accounting under the international statistical guidelines that the Bureau of Economic Analysis follows.

${ }^{2}$ Data on parent and affiliate value added are from Bureau of Economic Analysis (2022b) and Bureau of Economic Analysis (2022g). The corporate profit data are from Bureau of Economic Analysis (2021g).
} 
tax jurisdictions, such as Bermuda. Increasingly common profit-shifting practices include transfer pricing and complex global structuring related to intangible capital, in which an MNE effectively underprices intangible capital when "sold" from one of its entities in a hightax jurisdiction to another of its entities in a low-tax jurisdiction or engages in a series of transactions among subsidiaries that are strategically located in order to reduce the MNE's effective global tax rate. ${ }^{3}$ For U.S. MNEs, these strategies allow them to book earnings in low-tax foreign affiliates in ways that are disproportionate to the economic activity carried out in those affiliates. ${ }^{4}$ These tax strategies have generated discussion among both the compilers and users of official statistics regarding the treatment of transactions within MNEs and their effect on national statistics. ${ }^{5}$

The effects of profit shifting on value added can be illustrated through a concrete example. Consider the iPhone, which is developed and designed in California but assembled by an unrelated company in China, with components manufactured in various (mostly Asian) countries. Taking some hypothetical ballpark figures, suppose the bill of materials and labor costs of assembly amount to $\$ 250$ per iPhone and the average selling price is $\$ 750$, for a gross profit of $\$ 500$ per phone. For simplicity, assume that there are no further costs of retailing and that all iPhones are sold to customers outside of the United States.

Two important questions arise from this simple scenario: First, defining GDP as total domestic value added, how much should each iPhone contribute to U.S. GDP? Second, given the profit-shifting practices described above, how much of each iPhone's gross profit is actually included in U.S. GDP?

To answer the first question, note that the $\$ 250$ paid to contract manufacturers and suppliers in Asia is not part of U.S. GDP, whereas how much of the $\$ 500$ gross profit should be attributed to U.S. GDP depends on where that value is created. If consumers are willing to pay a $\$ 500$ premium over the production cost for an iPhone, it is because they value the design, software, brand name, and customer service embedded in the product. If we

\footnotetext{
${ }^{3}$ Another common strategy is to have subsidiaries in high-tax jurisdictions borrow funds from the subsidiaries in low-tax ones, thereby reducing the profits in the former and raising them in the latter.

${ }^{4}$ See Grubert and Mutti (1991) and the subsequent literature.

${ }^{5}$ See, for example, Lipsey (2009; 2010), Rassier (2017), United Nations, Eurostat, and Organisation for Economic Co-operation and Development (2011), United Nations (2015), and the proceedings of a March 2018 meeting of the NBER Conference on Research in Income and Wealth (conference.nber.org/confer/2018/CRIWs18/summary.html). Although the OECD's transfer pricing guidelines call for an "arm's-length principle," which requires firms to apply market prices to related-party transactions, this is difficult to do in practice because many intrafirm transactions do not have market equivalents. For example, how should Apple value the intellectual property, marketing, and brand associated with the iPhone, when these intangible assets are developed in the United States but used in foreign subsidiaries? These intangibles are not traded in organized markets, so it is very difficult to judge whether the assigned values are correct.
} 
assume these intangibles were developed by managers, engineers, and designers at Apple headquarters in California (Apple, U.S.), then the entire $\$ 500$ should be included in U.S. GDP. In the national accounts, the $\$ 500$ would be a net export under "charges for the use of intellectual property" in expenditure-based GDP, matched by an increase in Apple's earnings in income-based GDP. To the extent that some intangible assets were created outside of the United States, only the appropriate share of the gross profit and related net exports would accrue to the United States.

As to the second question, the gross profit actually included in U.S. GDP may be small as a result of national accounting conventions. Suppose that Apple generates intangible assets in the United States and legally transfers them to a foreign affiliate (e.g., one in Ireland). Payments for the use of intellectual property will accrue in Ireland rather than in the United States, which means that the returns to Apple U.S.'s intangible assets are attributed to an Apple affiliate outside the United States and not included in U.S. GDP. In this case, the returns are captured in "income on U.S. direct investment abroad (USDIA)," which is used, along with foreign direct investment in the United States (FDIUS), to calculate U.S. gross national product (GNP),

$$
G N P_{t}=G D P_{t}+\text { income on } \mathrm{USDIA}_{t}-\text { income on } \mathrm{FDIUS}_{t}+/-\cdots
$$

Thus, relative to the conceptual measure, U.S. net exports, corporate profits, and GDP are understated and earnings on USDIA are overstated. ${ }^{6}$

Profit shifting results in retained profits and other assets accumulating in foreign affiliates, particularly in affiliates located in low-tax jurisdictions (Foley, Hartzell, Titman, and Twite, 2007). To illustrate the prevalence of this situation, Table I reports, by host country, the total assets (cash, receivables, property, plant, and equipment, etc.) owned by the foreign affiliates of U.S. MNEs relative to several production-related measures. ${ }^{7}$ Canada is not considered a low-tax jurisdiction but is an important destination for U.S. foreign direct investment. The other countries in the table are the well-known "tax havens" in Europe, the Caribbean, and Asia. The ratio of total assets to physical capital (property, plant, and equipment; PPE) for U.S.-owned foreign affiliates in Canada is 6.4, whereas this ratio averages almost 300 for European tax havens Ireland, Luxembourg, the Netherlands, and Switzerland, and more than 90 for Barbados, Bermuda, and the U.K. Caribbean Islands.

\footnotetext{
${ }^{6}$ Income on FDIUS is income earned on foreign direct investment in the United States, the foreign counterpart to income on U.S. direct investment abroad.

${ }^{7}$ Data for PPE are from Bureau of Economic Analysis (2022e), for compensation are from Bureau of Economic Analysis (2022c), for employment are from Bureau of Economic Analysis (2022d), and total assets are from Bureau of Economic Analysis (2022f).
} 
TABLE I - Assets in U.S.-owned foreign affiliates, 2012

\begin{tabular}{lrrr}
\hline & \multicolumn{2}{c}{ Ratio of U.S.-owned foreign affiliate total assets to } \\
\cline { 2 - 4 } & PPE & Compensation & $\begin{array}{c}\text { Employment } \\
\text { (mil. USD) }\end{array}$ \\
\hline World & 16.8 & 39.0 & 1.8 \\
Canada & 6.4 & 21.2 & 1.2 \\
Ireland & 20.0 & 142.7 & 10.9 \\
Luxembourg & $1,019.6$ & $1,380.0$ & 121.6 \\
Netherlands & 97.7 & 115.3 & 8.7 \\
Switzerland & 59.9 & 60.0 & 7.7 \\
Barbados & 41.8 & $1,444.7$ & 43.3 \\
Bermuda & 130.8 & $1,475.5$ & 195.8 \\
U.K.I., Caribbean & 101.2 & $3,330.2$ & 2.7 \\
Hong Kong & 40.3 & 39.3 & 3.1 \\
Singapore & 18.6 & 50.3 & \\
\hline
\end{tabular}

Notes: Adapted from Lipsey (2010). Total assets are the sum of all financial (e.g., cash, receivables) and non-financial (e.g., PPE, inventories) assets on a historic cost basis - that is, amounts reported on firms' financial statements under U.S. generally accepted accounting principles (GAAP). United Kingdom Islands (U.K.I.), Caribbean, consist of the British Virgin Islands, Cayman Islands, Montserrat, and Turks and Caicos Islands.

Measuring assets relative to employment (number of employees) or compensation yields similar patterns. ${ }^{8}$

The goal of this paper is to calculate an alternative measure of U.S. GDP and several key aggregate statistics by adjusting for the effects of MNE profit shifting on value added. For this purpose, we use confidential MNE survey data, collected by the Bureau of Economic Analysis (BEA) for the period 1982-2016. ${ }^{9}$ The survey data cover the worldwide operations of U.S. MNEs and contain, among other key measures, information on their employment, $\mathrm{PPE}$, and R\&D expenditures. We also use annual data for transactions in income on direct investment published by BEA in the International Transactions Accounts (ITAs), also available for 1982-2016.

Profit shifting confounds the relationship between the location of economic activity

\footnotetext{
${ }^{8}$ These cross-border strategies can wreak havoc on the official statistics of economies like Ireland and the Netherlands. As one example, annual Irish GDP growth in 2015 was 26 percent, compared to a consensus forecast by economists of 7.8 percent. This large discrepancy was almost entirely due to the unexpected movement of legal ownership of MNE assets to the country (Eurostat, 2016).

${ }^{9}$ The firm-level survey data, which by law are confidential, are collected for the purpose of producing publicly available aggregate statistics on the activities of multinational enterprises.
} 
and the location of reported profit. To realign reported profit and economic activity, we use the firm-level data to reattribute earnings on USDIA among a U.S. parent and its foreign affiliates. This reattribution method is derived from a simple model of profitmaximizing firms and implies that the total worldwide earnings of an MNE are attributed to its constituents based on their shares of the MNE's global wage bill, physical capital stock, or stock of intangible capital. It should be noted, however, that our simple method assumes away real factors that can create differences in the returns to productive factors in different locations. Primarily for this reason, our results should be interpreted as estimates rather than exact measurements.

Since the aggregate earnings of U.S. MNEs are disproportionately booked to low-tax jurisdictions with little real economic activity, our adjustment reattributes their reported earnings toward the United States and other higher-tax jurisdictions, thereby increasing measured U.S. GDP. We use our estimates to compute an adjusted measure of domestic business-sector value added and related statistics for the United States, for 1982-2016.

For comparability with earlier work (Fernald, 2015), we use domestic business-sector value added as our measure of output. From 1982 to 1999, our adjusted series is never more than 0.6 percent larger than official business-sector value added. Starting in the late 1990s, profit shifting, and the resulting adjustments, grow rapidly. Profit shifting peaks in 2010 resulting in an adjustment that is more than 1.7 percent larger than official business-sector value added. Profit shifting has since ebbed, and our adjustment is about one percent larger than official business-sector value added for 2013-2016. Our estimated profit shifting is concentrated into a few sectors that include intangible-intensive industries such as electronics manufacturing, pharmaceuticals, and information technology. When we partition our sample by R\&D intensity, we find that profit shifting raises value added in these sectors by as much as 6.6 percent in 2008. In the non-R\&D intensive firms, profit shifting never increases value added by more than one percent.

Our methodology for estimating profit shifting does not use data on tax rates nor does it make a priori assumptions about "tax haven" countries. We find, however, that most of the profit shifted out of the United States is shifted to low-tax jurisdictions. For example, 42 percent of the total adjustment in 2016 is derived from the Netherlands and 30 percent is from Bermuda. Ireland, Luxembourg, and the U.K. Caribbean Islands round out the list of top profit-shifting destinations. Besides the United States, we find that higher-tax countries such as France, Germany, and Italy receive positive adjustments to their earnings on USDIA reported in official statistics.

Adjusting for profit shifting affects many aspects of economic measurement. We address 
four important ones here. First, when we add the shifted profit to corporate income, we need to also make an adjustment to the expenditure accounts. This manifests as an increase in U.S. exports, shrinking the trade deficit, e.g., in 2016, from 2.6 percent of GDP to 1.8 percent. If we assume that profit shifting is only occurring through intangible asset allocation, then our adjustment would leave the existing goods trade deficit unchanged and increase the existing services trade surplus.

Second, shifting profits out of foreign affiliates decreases the rate of return on USDIA. Our profit-shifting adjustment narrows the gap between the rate of return on USDIA and the rate of return on FDIUS - helping to resolve the investment-income puzzle (Albertus, 2019; Gourinchas and Rey, 2007). For the period 1982-2016, the average rate of return on USDIA falls from 11.7 percent to 7.3 percent, while the (unadjusted) return on FDIUS is 4.6 percent. ${ }^{10}$ The adjustment matters more in the later part of our sample. From 2005-2016, the adjusted rate of return on USDIA is 6.9 percent while the (unadjusted) return on FDIUS is 6.2 percent. Our adjustment dramatically decreases the rate of return on FDI in tax haven countries from 14.2 percent to 1.7 percent and has a smaller effect on the rate of return in non-tax-haven countries, lowering the rate of return from 10.3 percent to 9.6 percent.

Third, the increase in value added we estimate implies that value added per worker (labor productivity) is affected by profit shifting. The growth in profit shifting during the 2000s is particularly interesting, as it coincides with the slowdown in productivity growth in official statistics (Fernald, 2015), which begins in 2004. Our adjustment raises productivity growth from 2004 to 2010 by 13 basis points per year, a modest increase that does not overturn the productivity slowdown. However, this modest effect at the aggregate level masks sizable effects for industries with widespread profit shifting. For example, when we classify 4-digit industries based on their R\&D intensity (a proxy for intangible capital), the upward revision to productivity growth for R\&D-intensive industries between 1999 and 2008 is 9 times larger than for non-R\&D-intensive industries (and 4 times larger than the aggregate).

The comparison of R\&D-intensive and non-R\&D-intensive industries reveals another pattern that - while not directly related to the adjustment - is relevant for the broader discussion about productivity growth. R\&D-intensive industries have seen much faster productivity growth - a factor of 3 times more - than the rest. This is another manifestation of the rising productivity dispersion across firms, and we extend this finding of divergence by two more decades. ${ }^{11}$ Finally, the fact that R\&D-intensive industries grew at

\footnotetext{
${ }^{10}$ We lack the data to adjust the return on FDIUS. We discuss this further in Section 6.

${ }^{11}$ Decker, Haltiwanger, Jarmin, and Miranda (2016) document, over the past 20 years, the rise of
} 
the remarkably fast pace of 4.7 percent per year compared with only 1.5 percent for the rest suggests that the slowdown in aggregate productivity growth was primarily driven by a slowdown in non-R\&D-intensive firms.

Fourth, the reattributed income we measure is an increase in domestic corporate profits. This is an increase in capital income, which lowers labor's share of aggregate income. There is significant interest in the recent downward trend in labor's income share (Autor, Dorn, Katz, Patterson, and Van Reenen, 2020; Karabarbounis and Neiman, 2014). In the aggregate, our adjustments imply that the measured labor share falls by 0.9 percentage points more than the labor share in official statistics (1987-2008). The concentration of our adjustment in a few industries implies that the largest differences in labor-share trends occur in NAICS sectors 33 (including electronics and computers) and 32 (including pharmaceuticals and petroleum). In NAICS sector 33, the adjusted labor share falls by 2.6 percentage points more than in official statistics (1987-2008) and, In NAICS sector 32, the adjusted labor share falls by 3.1 percentage points more (1987-2008).

Finally, while our focus is on the profit shifting of U.S. MNEs, for some of the same reasons, foreign MNEs may have also shifted profits out of the United States, having a further downward effect on measured U.S. GDP. The BEA surveys cover the U.S. affiliates of foreign MNEs but unfortunately do not cover (most of) their foreign operations, including their foreign parent operations. Without this latter piece of data, estimating adjustments for foreign MNEs with the BEA survey data alone is not feasible. It is possible, however, to combine data from commercial databases to make progress on this question, and, in Section 6, we construct a data set of the largest technology-intensive foreign MNEs that have operations in the United States. Our results indicate a similar profit-shifting behavior by these corporations, further affecting measured U.S. GDP and the related measures. In our admittedly incomplete analysis, we find the magnitudes of the effects for foreign MNEs to be smaller than those for U.S. MNEs.

\subsection{Related literature}

Most of the evidence of MNE profit shifting comes from cross-country regressions of MNE profits (or income) on tax rates. Dharmapala (2014) provides a comprehensive survey. These studies find a strong relationship between differential tax rates and income attribution. In contrast, we do not use tax rate data in our methodology, however, consistent with the previous literature, we find the largest effects of profit shifting in the well-known

productivity dispersion across firms in the United States. Andrews, Criscuolo, and Gal (2016) find similar patterns in as study of OECD countries. 
"tax havens." In Section 4.3, we estimate the semi-elasticity of profits to tax rates in ways consistent with the early literature and arrive at very similar results.

In the literature that uses microdata to study profit shifting, Clausing (2016) uses aggregate data from the same data set that we use to estimate profit shifting in U.S. MNEs. Using estimates of the elasticity of MNE income to tax rates, she computes the cross-country distribution of MNE income under the counterfactual that all countries tax profits at 30 percent. The difference between the counterfactual income levels and the observed income levels is attributed to profit shifting. For 2012, she finds profit shifting to be $\$ 258$ billion, compared with our estimate of $\$ 144$ billion. Clausing (2016) uses her estimates to compute forgone tax revenues, while our focus is on measurement in the real economy. $^{12}$

Most similar in approach to our work is Torslov, Wier, and Zucman (2020). Like we do, they use simple relationships derived from profit maximization to estimate aggregate profit shifting. Our data allow us to estimate profit shifted by U.S. multinationals while Torslov, Wier, and Zucman (2020) derive a measure of profit shifting by all of the world's multinationals. In 2015, we estimate U.S. shifted profit to be $\$ 157$ billion while they estimate $\$ 143$ billion. Using aggregate data, they estimate profit shifting for a large number of countries for 2015, whereas we study only the United States going back to 1982. Our time-series approach puts the 2015 estimates in perspective: Our estimated $\$ 157$ billion of shifted profit is down more than 17 percent from peak profit shifting in 2010.

Compared to Torslov, Wier, and Zucman (2020), the microdata we use allow us to provide more detail regarding the industry in which profit shifting takes place and the characteristics of the firms shifting profits. For example, we find that profit shifting is concentrated in firms with significant R\&D spending. This evidence provides support for the theory that firms use intangible assets to facilitate profit shifting. Another important benefit of the microdata is that we directly observe which countries U.S. firms are shifting profits in to and out of, whereas Torslov, Wier, and Zucman (2020) allocate shifted profit as being proportional to variables such as service exports. We find their approach and ours to be complementary and the similarity of our aggregate results an important robustness check for both studies.

As we discuss in Section 2, our method can be interpreted as the formulary apportion-

\footnotetext{
${ }^{12}$ Our adjustments are different than those in Clausing (2016) because we use a net adjustment concept. We calculate net adjustments (i.e., adjustments for directly held affiliates less adjustments for indirectly held affiliates) using the microdata. Our aggregate adjustment for directly held affiliates in 2012 is $\$ 290$ billion. Online Appendix C presents our aggregate adjustment for each year, broken down into adjustments for directly held affiliates and indirectly held affiliates.
} 
ment approach that has been primarily applied in multijurisdictional tax practice. The treatment of global income under formulary apportionment is widely explored in multidisciplinary research, and formulary apportionment has been proposed as an alternative to the complexity and subjectivity of transfer pricing for the allocation of international tax obligations within MNEs. ${ }^{13}$ We do not, however, view our profit shifting estimates as the outcome of imposing a formulary tax system. Changing taxes (any of them) would generate endogenous responses by firms, which would have to be modeled.

In Section 2, we present our method for reattributing profits within the firm and how this is reflected in GDP. In Section 3 we discuss the data. In Section 4, we present our estimates of profit shifting and discuss their time-series, geographical, and industrial composition. In Section 5, we report the impact of our adjustments on several aspects of economic measurement, and show how our adjustments matter more for R\&D-intensive firms and industries. Section 6 takes a preliminary look at measurement of the foreign MNEs operating in the United States and Section 7 concludes.

\section{Measurement framework}

The data on U.S. MNEs from the BEA surveys report, among other variables, profits, compensation, R\&D expenditures, PPE, and identifying characteristics such as country and industry of operation. We observe these data for the parent and each affiliate in an MNE. We discuss the details of the data set in the next section. The issue at hand is that the profits reported in each location do not necessarily reflect the profit earned in that location: Unpriced shared resources and profit shifting among entities in the MNE can lead to a disconnect between the two. Our goal is to estimate a measure of the profit earned in each entity of the MNE. We take the difference between the estimated profit and the reported profit to be the profit shifted to or from the entity. We construct our profit measures so that total profit within the MNE remains constant-our procedure reapportions worldwide profit across the members of an MNE.

Our adjustment is computed for each year. We omit time subscripts for simplicity. Assume that an entity $n$ within an MNE $m$ operates the production function $y_{m n}=$ $\theta_{m n} k_{m n}^{\alpha_{m n}} \ell_{m n}^{\gamma_{m n}} h_{m n}^{1-\alpha_{m n}-\gamma_{m n}}$, where $k$ is physical capital, $\ell$ is labor, $h$ is intangible capital, and

\footnotetext{
${ }^{13}$ See, for example, Avi-Yonah (2010), Avi-Yonah and Benshalom (2011), Avi-Yonah and Clausing (2007), Fuest, Hemmelgarn, and Ramb (2007), and Runkel and Schjelderup (2011). Rassier (2014) and Rassier and Koncz-Bruner (2015) propose formulary apportionment as an alternative method for attributing the profits component of income-based value added to foreign affiliates of U.S. MNEs. They do not, however, consider the consequences for other measurements or the distribution of profit shifting across countries, industries, firms, and time.
} 
$\theta$ is productivity. We can write the profits earned in an entity as

$$
\pi_{m n}=y_{m n}\left[p_{m n}-c_{m n}\left(w_{m n}, r_{m n}, q_{m n}\right)\right]
$$

where $p$ is the price of the entity's output and $c_{m n}\left(w_{m n}, r_{m n}, q_{m n}\right)$ is the unit cost function associated with the production function. $w$ is the wage, $r$ is the rental rate of capital, and $q$ is the rental rate of intangible capital. Profit shifting means that profits reported in the data $\left(\pi_{m n}^{\text {reported }}\right)$ may differ from $\pi_{m n}$. Our goal is to recover $\pi_{m n}$ from the available data.

Consider allocating profits using factor payments. We take labor compensation as an example. Profit maximization implies that the profits of an entity can be expressed as

$$
\pi_{m n}=w_{m n} \ell_{m n}\left(\mu_{m n}-1\right) / \gamma_{m n}
$$

where $\mu=p / c(r, w, q)$ is the gross markup. If $\mu$ and $\gamma$ are identical across entities in the MNE, then we can compute the entity's profits as its share in the global wage bill times the global profits of the MNE,

$$
\pi_{m n}=\frac{w_{m n} \ell_{m n}}{\sum_{k=1}^{N_{m}} w_{m k} \ell_{m k}} \times \pi_{m}
$$

where $\pi_{m}$ is the sum of the profits of each entity in the MNE. ${ }^{14}$

We observe everything on the right-hand side of (4), which allows us to estimate the profit earned in each entity in the MNE, which we denote $\hat{\pi}_{m n}$. When markups and labor shares are identical within the MNE, $\hat{\pi}_{m n}=\pi_{m n}$.

How does our estimator behave if there is intra-MNE heterogeneity in markups and labor shares? We can rewrite (4) as a function of the weighted average of all of the markups and labor shares in the MNE,

$$
\hat{\pi}_{m n}=\pi_{m n}\left(\frac{\mu_{m n}-1}{\gamma_{m n}}\right)^{-1} \sum_{i=1}^{N_{m}} \frac{w_{m i} \ell_{m i}}{\sum_{k=1}^{N_{m}} w_{m k} \ell_{m k}} \frac{\mu_{m i}-1}{\gamma_{m i}} .
$$

If the entity has a larger markup-labor-share ratio compared with the compensationweighted average within the MNE, then $\hat{\pi}_{m n}<\pi_{m n}$. Note that factor prices and productivity $\left(\theta_{m n}\right)$ do not need to be identical across entities within MNEs, and markups and labor shares do not need to be identical across MNEs.

\footnotetext{
${ }^{14}$ To see this, replace $\pi_{m}$ with the sum of $\pi_{m n}$ and substitute (3). Further details are available in Online Appendix A.
} 
Expressions analogous to (4) also hold for physical-capital payments $\left(r_{m n} k_{m n}\right)$ and intangible-capital payments $\left(q_{m n} h_{m n}\right)$. In theory, each of these approaches should yield the same estimate for profit earned, but measurement error and differences in markups and production technologies across entities will generate different profit estimates. In light of this, we propose a simple weighted average of the three approaches,

$$
\hat{\pi}_{m n}=\frac{1}{3}\left[\frac{w_{m n} \ell_{m n}}{\sum_{k=1}^{N_{m}} w_{m k} \ell_{m k}}+\frac{r_{m n} k_{m n}}{\sum_{k=1}^{N_{m}} r_{m k} k_{m k}}+\frac{q_{m n} h_{m n}}{\sum_{k=1}^{N_{m}} q_{m k} h_{m k}}\right] \times \pi_{m} .
$$

The average of the three factors is easy to compute and the data are available for almost all of the entities in our data set. In the multijurisdictional tax literature, this approach is known as formulary apportionment. We adopt this language, referring to compensation and physical- and intangible-capital payments as apportionment factors and $\epsilon_{m n}=\hat{\pi}_{m n}$ $\pi_{m n}^{\text {reported }}$ as the adjustment for entity $n$. We do not, however, view our measurements as the counterfactual outcome of taxation based on formulary apportionment. Changing to a formulary tax system would generate an endogenous response by MNEs, which we would need to model.

We are focused on the adjustment to the U.S. parent of the MNE. We adopt the convention that the parent is the first entity, $n=1$. The aggregate adjustment to the United States is the sum of the $\epsilon_{m 1}$ over all MNEs. We analyze this aggregate adjustment in Section 4 and discuss its implications in Section 5.

\subsection{National accounting}

When we reattribute profits to the United States, we are decreasing income reported as earned on direct investment abroad. In the national income and product accounts, we need to make a second entry to match the change in income earned on direct investment. How we make this second entry depends on how the MNEs are shifting profits. The three profit shifting methods most often discussed are: 1) Pricing goods and services sold within the firm so that the high-tax affiliate earns small profits and the low-tax affiliate earns large profits (transfer pricing of goods and services); 2) Pricing intrafirm financial transactions so that high-tax affiliates make large payments to low-tax affiliates (essentially, transfer pricing of loans); and 3) Moving ownership of intangible assets to low-tax affiliates at a

price below their true value and charging high-tax affiliates for the use of the intangible assets (essentially, transfer pricing of intangible-asset services).

Our adjustments are not informative about the profit-shifting methods used-they will return the same estimated profits under any form of profit shifting. The multinational tax 
literature, as well as our analysis below, finds convincing evidence that suggests MNEs are using intangible assets to shift profits. Thus, we assume that all profit shifting is carried out through intangible asset transactions. This assumption implies that the profits we reattribute to the United States are for the use of intangible assets, and the additional U.S. profits should be accompanied by an increase in U.S. exports of services.

$$
\begin{aligned}
\text { GDP }^{\text {income }} & =\text { compensation of employees }+\uparrow \text { corporate profits }+\cdots \\
\text { GDP }^{\text {expenditure }} & =\text { consumption }+\uparrow \text { exports }^{\text {services }}+\text { exports }^{\text {goods }}+/-\cdots
\end{aligned}
$$

This assumption has no impact on our results, except for our adjustment to the trade balance discussed in Section 5.1. Our assumption means that the services trade balance will increase, but the goods trade balance will be unchanged. To the extent that some profit shifting is happening through transfer pricing of goods, the goods trade balance would need to be adjusted, too.

Given our assumptions, one dollar of earnings on USDIA reattributed to the parent will increase corporate profits and, thus, income-based GDP, by one dollar. In order to balance the expenditure account, the implication is that "charges for the use of intellectual property" (an export of services) and, thus, expenditure-side GDP, will also increase by one dollar. The current account balance of the balance-of-payments account remains unchanged because the increase in exports offsets the decrease in earnings on USDIA.

\section{Constructing the adjustment}

We focus on domestic business-sector value added from the National Income and Product Accounts (NIPAs) published by BEA, which abstracts from the household, government, and nonprofit sectors of the economy. Following (6), we construct adjustments to businesssector value added using annual survey data collected by BEA on U.S. MNEs. The survey data include financial and operating activities based on income statement and balance sheet information reported under U.S. GAAP for U.S. parents and their foreign affiliates. In accordance with International Monetary Fund (2009), an enterprise is an affiliate of the parent enterprise when the parent owns at least 10 percent of the enterprise's voting stock or equivalent. ${ }^{15}$ These surveys are required to be completed for all U.S. parents, and surveys are required to be completed for all foreign affiliates based on thresholds for assets, sales,

\footnotetext{
${ }^{15}$ In 2016, 86 percent of affiliates were majority-owned by their U.S. parents and 78 percent were whollyowned.
} 
and net income. From these surveys, we use, for each parent and affiliate, compensation, net property, plant, and equipment stocks, and stocks of intangible capital, which we use as apportionment factors. The surveys are also our source of earnings reported on U.S. parents and foreign affiliates, as well as the U.S. parent's reported voting interest in a foreign affiliate.

To construct adjusted aggregate output, we need the apportionment factors and profits for each entity in each MNE.

\subsection{Apportionment factors}

We use compensation of employees (wages and salaries plus employer-paid benefits), net PPE stocks, and stocks of intangible capital as apportionment factors. Each factor has advantages and disadvantages.

Compensation reflects both the number of employees and their wages. If workers are paid their value marginal product, then compensation reflects variation in economic activity across industries and countries. Compensation is based on market transactions rather than financial accounting conventions, and, thus, adjustments constructed using only compensation may provide the most objective measure of economic activity. Compensation, however, may not reflect the actual economic owner of intangible capital and may not reflect the provision of services through means such as digital technology, which do not require a physical presence.

Net PPE stocks represent the net book value of property, plant, and equipment-based on financial accounting records. It covers structures, machinery, equipment, special tools, deposit containers, whether owned outright or held under a capital lease. It also includes construction-in-progress, capitalized tangible and intangible exploration and development costs and land, timber, mineral rights and similar rights owned. For foreign affiliates, the data are from annual BEA surveys. For U.S. parents, survey data are available only in quinquennial benchmark years. Firm-level parent data for the interim years were generated using linear interpolation and extrapolation. ${ }^{16}$

Intangible capital stocks were generated annually at the parent and affiliate level using BEA survey data on R\&D expenditures and a perpetual inventory method. The method uses an assumed annual depreciation rate of 26 percent, which is based on an average of depreciation rates that are used for R\&D capital stocks in the U.S. Fixed Assets Accounts (Bureau of Economic Analysis, 2022a).

\footnotetext{
${ }^{16}$ In addition, we confirm the robustness of our results with use of capital expenditures in lieu of net PPE because capital expenditures are reported each year for U.S. parents.
} 
Note that we are using stocks of physical and intangible capital, rather than the payments to these factors as dictated by (3). Our data do not include the rates of return on these assets. If factor returns differ across different entities of an MNE, this will influence our measurement - an issue we avoid when we use compensation of employees. ${ }^{17}$

\section{$3.2 \quad$ Economic profits}

There are several profits measures in the BEA MNE data, each one serving a different purpose. For our research, the most important features are that the measure of profits reflects current production and avoids double counting so that we can compute an accurate measure of the worldwide MNE profits to be reapportioned (Blouin and Robinson, 2020). Among the BEA profits measures, there are two that reflect current production and avoid double counting: direct investment earnings and profit-type return. We focus on direct investment earnings for three reasons. First, and most importantly, direct investment earnings is one of the components used to derive GNP from GDP, and the essence of our adjustment is a reallocation of earnings from GNP to GDP. Second, direct investment earnings covers all foreign affiliates whereas profit-type return covers only majority-owned foreign affiliates. Third, direct investment earnings is less likely to be affected by incomplete knowledge or incomplete reporting on BEA surveys of the full scope of the ownership hierarchies within the MNE. By using direct investment earnings, we are reapportioning profits from where they are booked to where they are earned. For a discussion of the various BEA profit measures and their uses, see Clausing (2020). ${ }^{18}$

Our measure of profits reflects current production that is consistent with the profits component of GDP calculated by the factor income approach. Profits of U.S. parents are calculated as net income minus capital gains and losses, minus profits of their foreign affiliates on which the U.S. parent has a claim, plus charges for depletion of natural resources. Profits of foreign affiliates on which the U.S. parent has a claim - our measure of foreign profits - are calculated as foreign affiliate net income minus capital gains and losses plus charges for depletion of natural resources, the result of which is multiplied by the parent's direct voting interest in the foreign affiliate. Profits of indirectly-held foreign affiliates are included in the equity income of the directly-held foreign affiliates so that coverage of the parent's share of foreign affiliate profits is complete. Nevertheless, this method of focusing

\footnotetext{
${ }^{17}$ To the extent that the MNE maximizes profits jointly across entities within the MNE, the internal capital market will equalize rates of return across entities.

${ }^{18}$ Transactions in income on USDIA include earnings and net interest receivable. Earnings include a U.S. parent's share of its foreign affiliate's net income less capital gains and losses, less income from equity investments, and plus depletion. Earnings are either distributed as dividends or reinvested as further direct investment. Net interest is very small relative to earnings on U.S. outbound direct investment and is not a production measure included in GDP, so we do not include it in our adjustments.
} 
on directly-held foreign affiliates does affect the country-by-country reallocations described in Section 4.2. Foreign profits are reapportioned from the location of their highest aggregation in the foreign affiliate ownership chain (the country by which they are classified in the U.S. international transactions accounts) to where they originated.

\subsection{Adjusted output}

We compute the entity-level adjustments and aggregate the parents' adjustments $\left(\epsilon_{m 1}\right)$ for all U.S. MNEs. We add this aggregate adjustment to nominal expenditure-based businesssector value added and to nominal income-based business-sector value added. Let $M$ be the set of all U.S. MNEs and $Y^{\mathrm{VA}}$ be either income- or expenditure-based nominal value added as officially reported. Adjusted value added, $\widehat{Y}^{\mathrm{VA}}$, is

$$
\widehat{Y}^{\mathrm{VA}}=Y^{\mathrm{VA}}+\sum_{m \in M} \epsilon_{m 1}
$$

We take the geometric average of the two adjusted value added series and deflate them using the implicit price deflator for business-sector value added. ${ }^{19}$

\section{The adjustment}

Figure 1A presents the aggregate adjustments as a share of business-sector value added: the sum of the $\epsilon_{m 1}$ from (9) divided by $Y^{\mathrm{VA}}$. Our baseline adjustment defined in (6) is labeled "weighted adjustment." We plot total income on USDIA for reference. In Figure $1 \mathrm{~B}$, we plot the adjustment in real dollars. ${ }^{20}$

From 1982 to 2000, the adjustments grow, but very slowly, and never exceed 0.6 percent of value added in any year. This changes in the early 2000s, as income on USDIA surges, and the weighted adjustments grow to more than 1.7 percent of value added. The cumulative increase in U.S. GDP from the adjustment is substantial. From 2000 to 2016, the weighted adjustment adds $\$ 2.05$ trillion to GDP. The adjustments peak in 2010 at $\$ 189$ billion and decrease to $\$ 140$ billion in $2016 .^{21}$

\footnotetext{
${ }^{19}$ Some requisite survey-level data on U.S. parents were not collected for 1983-1988 and 1990-1993. However, aggregate statistics on transactions in income (direct investment income and portfolio income) are available for all years. We linearly interpolate the nominal adjustment for 1983-1988 and 1990-1993.

${ }^{20} \mathrm{An}$ earlier version of this paper, titled "Offshore profit shifting and domestic productivity measurement," reported results using gross direct investment income. The results reported here are based on net direct investment income. Our qualitative findings are unchanged, but the magnitude of our adjustments are attenuated.

${ }^{21}$ In related work, Torslov, Wier, and Zucman (2020) estimate profit shifting by all of the world's MNEs (relative to tax harmonization) in 2015. They find an adjustment to the United States of $\$ 142.6$ billion compared with our estimate of profit shifting by only U.S. MNEs of $\$ 156.5$ billion.
} 
FiguRE 1 - Aggregate adjustments

(A) As share of business-sector value added

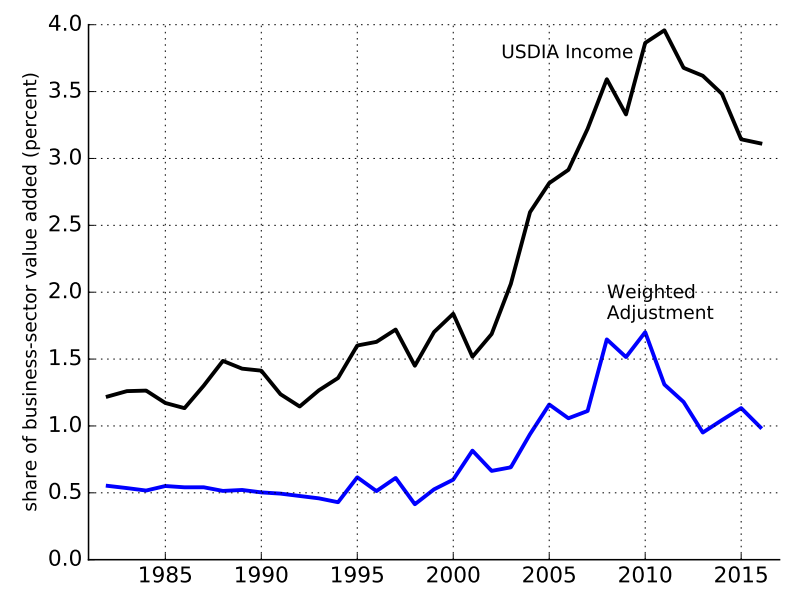

(B) Inflation-adjusted level

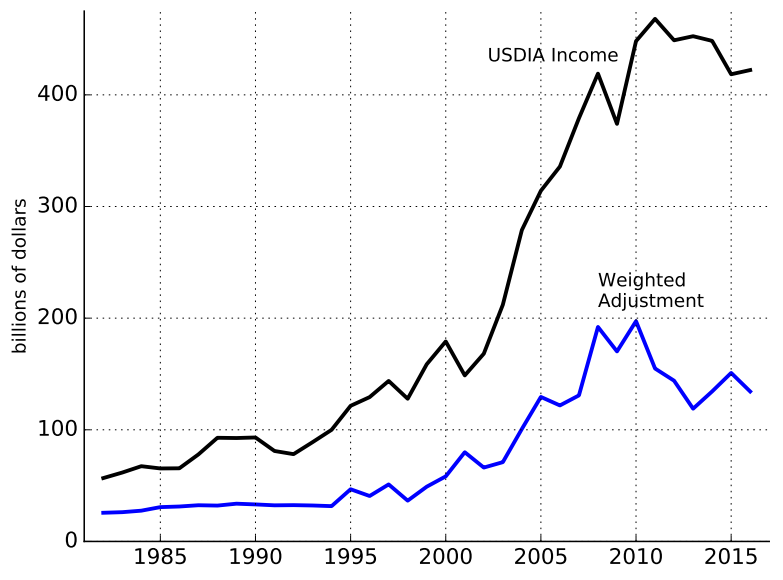

In Figure 2A, we plot the adjustment when either compensation, physical capital, or intangible capital is the only factor used to compute the apportionment weights, as in (4). From 2000 to 2016, the weighted adjustment adds $\$ 2.05$ trillion to GDP. Over the same period, the compensation-based adjustment adds $\$ 1.78$ trillion, the PPE-based adjustment adds $\$ 1.47$ trillion, and the intangible-capital-based adjustment adds $\$ 2.73$ trillion. The adjustment derived from only intangible capital reflects the fact that MNE R\&D spending is largely done by the parent.

Figure 2B gives a sense of the variability of our adjustment. We compute the weighted adjustment in 100 bootstrapped samples of our data and report the 25 th and 75 th percentile adjustment as dashed lines. The shaded area corresponds to two-standard-deviation bands around the adjustment. Prior to about 2005, the variance around the adjustment is quite small. It increases somewhat after 2008 and the standard deviation in 2016 is $\$ 27.2$ billion. 
Figure 2 - Robustness

(A) Weighting schemes

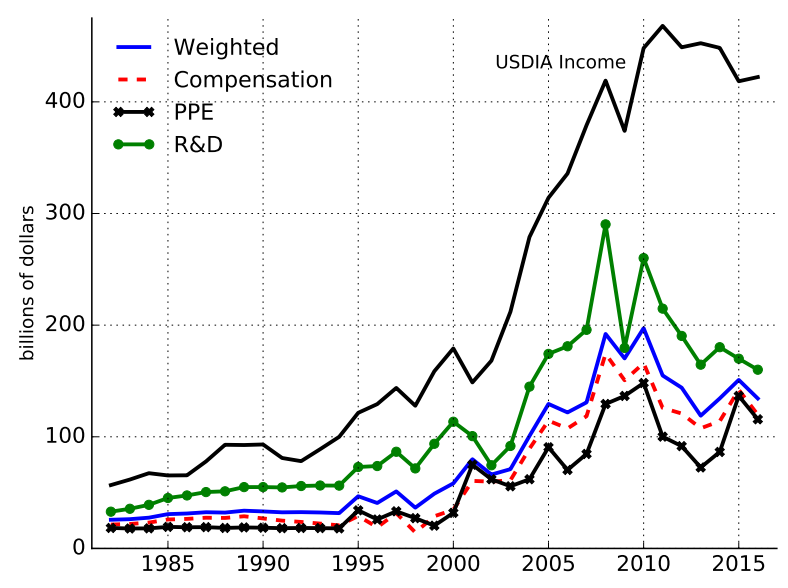

(B) Variation

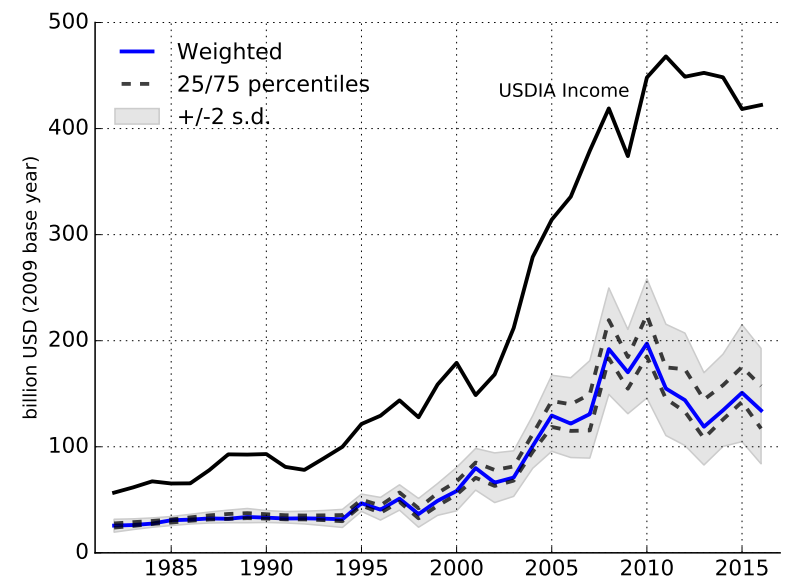

\subsection{The dynamics of aggregate profit shifting}

In this section, we examine the factors that shaped the evolution of the aggregate adjustment: its rapid growth from the late-1990s to 2010 and its tapering off thereafter.

\section{Tax laws and regulations}

The rise in profit shifting in the 1990s spurred enormous research interest in academics (e.g., tax scholars in accounting, economics, and law) as well as in government agencies (e.g., the Department of the Treasury and Congress). The research identifies three changes in tax regulations as important drivers of the rise in profit shifting in the 1990s and its tapering off in the last decade. Here, we briefly summarize the most relevant parts of these tax regulations and provide a more extensive discussion in Online Appendix D.

The rise in profit shifting coincides with two major changes in tax regulation in the 1990s. The first is the 1995 revision of IRS regulations on cost sharing agreements (CSAs). In a CSA, one geographic unit of an MNE-typically a foreign affiliate in a tax haven country - shares the cost of developing a new technology with its U.S. parent and, in return, is granted rights to royalties on a portion of the sales of products or services using that technology. This change made it much easier for MNEs to use CSAs to transfer their intellectual property at advantageous prices to their foreign affiliates, which then collect the royalties and profits accruing to those intellectual properties.

The second change occurred in 1997 when the IRS introduced what would become known as the "check-the-box" regulation, which aimed to simplify how U.S. corporations classified their various subsidiaries. Check-the-box allowed a U.S. MNE to disregard a 
foreign affiliate by "checking the box" on Form 8832. When a disregarded entity receives a payment from another entity in the enterprise, this transaction is not taxable, as the payment is viewed as occurring within a consolidated entity. This change made it easier for U.S. MNEs to set up chains of foreign affiliates whose payments to each other were not taxed by the IRS. This arrangement made profit shifting an even more effective tax reduction strategy because now a U.S. MNE could also shift profits from its foreign subsidiaries in higher-tax jurisdictions to the one(s) in tax havens, without making those transfers a taxable event from the perspective of the IRS.

The pivotal role played by CSAs and check-the-box regulation for driving profit shifting was well understood by tax authorities, tax scholars, and MNEs. ${ }^{22}$ Starting in the mid2000s, the IRS increased its efforts to reduce the tax base erosion caused by profit shifting and tightened the rules governing CSAs, issuing Temporary Regulations in 2008 and Final Regulations in 2011. In testimony to the U.S. Senate in 2013, Harvard law professor Stephen Shay described the pre-2011 regulations as "much more relaxed" than the post-2011 regulations (Senate Committee on Homeland Security and Government Affairs, 2013). This comment suggests that the combined IRS guidance on "buy-in payments" and "platform contributions" gradually made it more difficult for MNEs to use CSAs to transfer intangible assets. The timing of these tighter new rules (as well as stricter enforcement) lines up very well with the tapering off of profit shifting - and hence in our adjustments. ${ }^{23}$

\section{Petroleum}

As we discuss in more detail below, the oil and gas industry accounts for a large share of our adjustments to U.S. GDP. Given the large swings in oil prices during our sample period, we examine how they have contributed to variation in our adjustments over time.

Companies in the petroleum industry often face resource taxes and royalties (in addition to corporate income taxes) that create strong incentives to manage tax liabilities. Perhaps in response to these incentives, the structure of firms in the petroleum industry lends itself to an array of profit shifting strategies. Exploration and production affiliates may be thinly capitalized, and transportation, insurance, hedging operations, and intercompany loans create transfer pricing opportunities. A U.S. multinational petroleum company,

\footnotetext{
${ }^{22}$ For example, in a 2007 report to the U.S. Congress, the Treasury Department wrote that " $\mathrm{t}$ ] $\mathrm{he}$ Treasury Department believes that CSAs under the current regulations pose significant risk of income shifting from non-arm's length transfer pricing (U.S. Department of the Treasury 2007)." For detailed summaries of how these regulations have affected profit shifting, see Sullivan and Cromwell, LLP (2011) and Senate Committee on Homeland Security and Government Affairs (2013).

${ }^{23}$ Sullivan and Cromwell, LLP (2011) discuss various pieces of evidence on how profit shifting and transfer pricing became a key focus for the IRS, especially after the mid-2000s. They also mention the creation of a new director-level position as evidence of a "heightened focus on transfer pricing issues" within the IRS.
} 
for example, agreed in 2017 to pay 340 million AUD in extra taxes to the Australian government in regard to intercompany loans that were made at above-market rates (Smyth, 2017).

In Figure 3A, we plot the price of crude oil, which was relatively stable around $\$ 20$ per barrel from about 1986 to 1999 but had a very strong run-up from 2000 to 2014, during which time it quadrupled to $\$ 93$ per barrel (Federal Reserve Bank of St. Louis, 2022). This rise in oil prices, coupled with the relatively inelastic demand for oil, boosted both domestic and foreign income earned by MNEs in this sector relative to the rest of the U.S. economy. If we assume that the propensity of U.S. MNEs in this sector to shift profits was unchanged, the sector's contribution to the aggregate adjustments will increase along with the rise in oil prices. In Figure 3B, we plot the aggregate adjustments that excludes the petroleum sector (dashed red line) against the baseline adjustment (solid blue line) reproduced from Figure 1. The gap between the two adjustments is small when the price of oil is low and grows large when the price of oil increases, peaking in 2010.

FiguRE 3 - The petroleum industry

(A) The price of West Texas Intermediate Crude

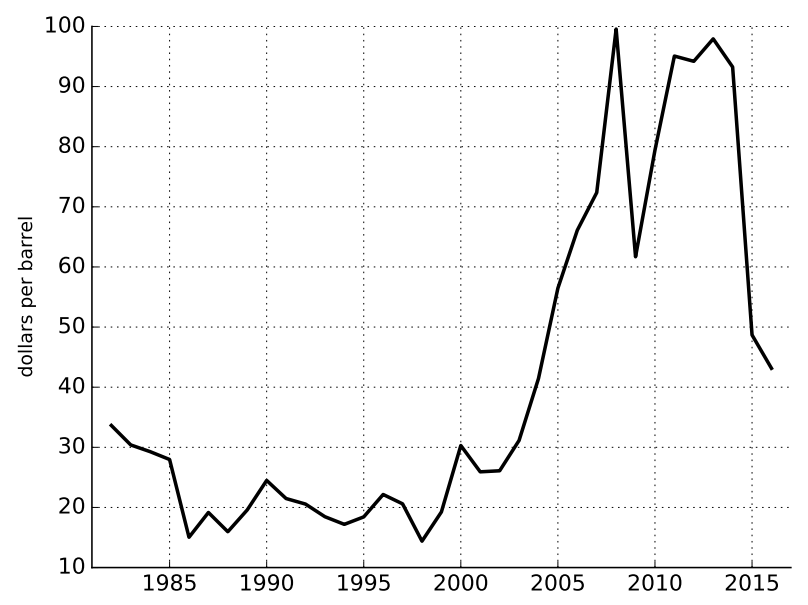

(B) The aggregate adjustment

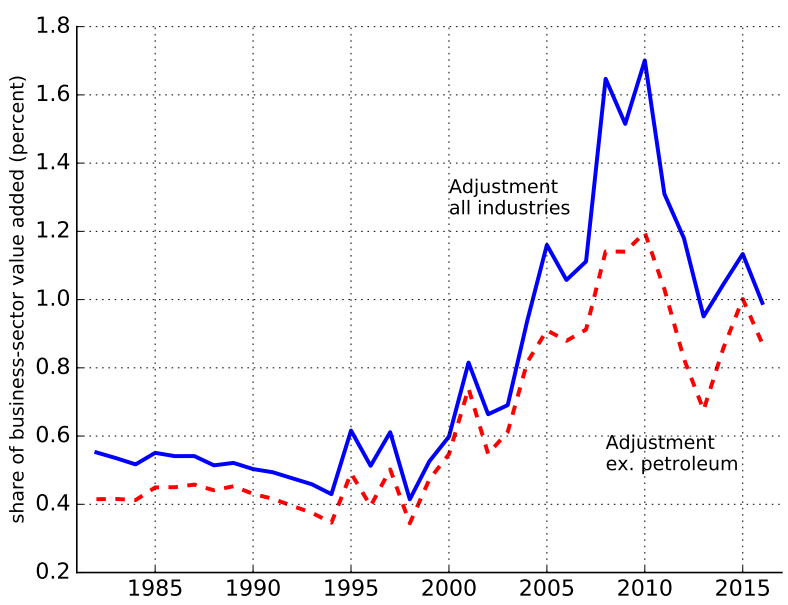

\subsection{Adjustments for other countries}

Our adjustments are reattributions of earnings on USDIA among the parent and foreign affiliates of each U.S. MNE. As evident in Figure 1, in 2016, 32 percent of earnings on USDIA are reattributed to the United States, which we treat as an increase in U.S. GDP. From which countries did these earnings on USDIA originate? The largest reattributions to the United States are concentrated in seven countries, all of which are considered to be low-tax (or high privacy) destinations for MNE profit shifting (Table II and Figure 4). 
TABLE II - Adjustments in other countries, 2016

\begin{tabular}{lcclcr}
\hline & \multicolumn{2}{c}{ Percent share of } & \multicolumn{2}{c}{ Percent share of } \\
\cline { 2 - 3 } \cline { 5 - 6 } & adjustment & DI income & adjustment & DI income \\
\hline $\begin{array}{l}\text { Decrease in earnings } \\
\text { Netherlands }\end{array}$ & 42.1 & 64.5 & Germany & 7.96 & 211.7 \\
Bermuda & 30.0 & 81.8 & France & 5.37 & 242.5 \\
Ireland & 23.1 & 54.3 & United Kingdom & 4.58 & 26.8 \\
Luxembourg & 17.8 & 65.2 & Canada & 4.01 & 26.8 \\
U.K.I., Caribbean & 21.0 & 84.2 & Italy & 3.68 & 296.3 \\
Switzerland & 12.1 & 46.9 & China & 3.08 & 34.6 \\
Singapore & 10.6 & 52.5 & Japan & 2.13 & 88.0 \\
\hline
\end{tabular}

Notes: The total adjustment in 2016 is $\$ 140.3$ billion. In the column DI income, we report the earnings adjustment minus net interest payments as a share of the published USDIA income for the country (Bureau of Economic Analysis, 2022h). The United Kingdom Islands (U.K.I.), Caribbean, include the British Virgin Islands, Cayman Islands, Montserrat, and Turks and Caicos Islands.

Consistent with the popularity of the "double Irish with a Dutch sandwich" tax reduction strategy (Sanchirico, 2015), the Netherlands is the largest source (42.1 percent) and Ireland is the third-largest source (23.1 percent) of earnings on USDIA reattributed to the United States. The top seven also includes tax havens Bermuda, Luxembourg, Singapore, Switzerland, and the U.K. Caribbean Islands.

Note that the earnings on USDIA reattributed away from countries does not mean that the GDP of those countries is overstated because earnings on foreign direct investment and GDP are different measurement concepts. In particular, earnings on foreign direct investment are measured on an immediate-counterparty basis, which means that profits from production at an indirectly-held foreign affiliate, such as an affiliate in Germany, are included in the equity income, and thus, earnings on USDIA of a directly-held foreign affiliate, such as an affiliate in the Netherlands. In contrast, the profits component of GDP is measured based on where production is presumably taking place, which, in the example, may be either Germany or the United States, as determined under our methodology by the apportionment factors for the parent and affiliates. ${ }^{24}$

\footnotetext{
${ }^{24}$ We can compare our estimates to those from Torslov, Wier, and Zucman (2020) for a handful of countries in 2015. Torslov, Wier, and Zucman (2020) estimate income shifted by all of the world's multinationals while our estimates capture profit shifting from only U.S. MNEs. We tend to attribute more income to the United States from these European tax havens than they do. We estimate $\$ 34.9$ bil. (vs. their $\$ 8.4$ bil.) for Ireland, $\$ 29.4$ bil. (vs. $\$ 14.2$ bil) for Luxembourg, $\$ 44.3$ bil. (vs. $\$ 14.4$ bil.) for the Netherlands and $\$ 15.8$ bil. (vs. $\$ 13.7$ bil.) for Switzerland. In our data, we observe the countries in which the MNE operates and directly measure profit shifting by host country. Torslov, Wier, and Zucman (2020) observe aggregate profit shifted and assume that profit shifting is proportional to bilateral service exports.
} 
FiguRE 4 - Geographical reattribution of earnings of U.S. MNEs, 2016 (bil. USD)

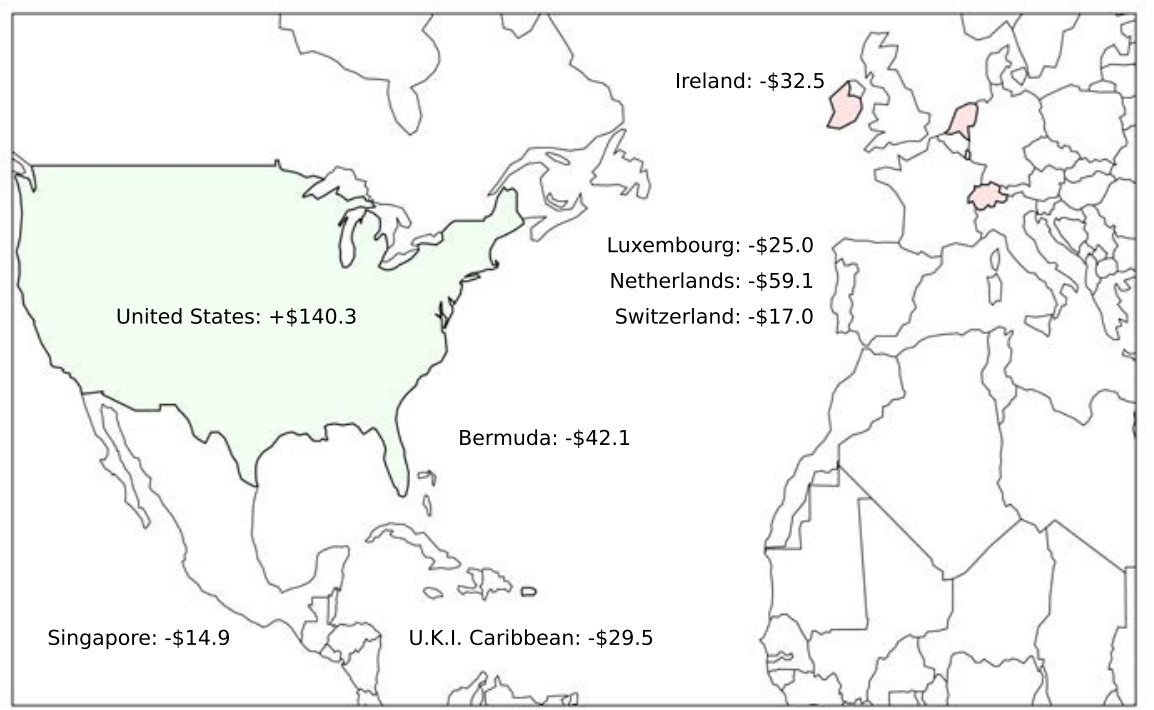

Notes: The United Kingdom Islands (U.K.I.), Caribbean, are made up of the British Virgin Islands, Cayman Islands, Montserrat, and Turks and Caicos Islands.

As a result, our adjustments are positive for some countries (besides the United States) as well. The seven countries with the largest positive reattribution of earnings on USDIA are listed in Table II. None of these countries are considered tax havens. Overall, the reattribution pattern supports the concern that profit shifting affects measurement as a result of earnings on USDIA being shifted to affiliates in countries with relatively low tax rates. $^{25}$

\subsection{Relationship to tax rates}

Our apportionment method does not use tax rate differences across countries; our method relies only on measures of economic activity. It is evident, however, that our measures of shifted profits are correlated with tax rate differentials. Much of the literature on profit shifting has looked for evidence of tax-motivated profit shifting by running cross-country

\footnotetext{
${ }^{25}$ While we show in Figure 2A that the adjustment in the United States is relatively invariant to the weighting scheme, this may not be true in other countries. In the online appendix, we report a version of Table II where we weight by only compensation, PPE, or R\&D stocks. The results are largely unchanged except for Ireland. The adjustments that use only compensation or R\&D stocks increase the amount of income reattributed away from Ireland from $\$ 32.5$ billion to $\$ 43.8$ billion and $\$ 44.4$ billion, respectively. When measured using only physical capital, the adjustment to Ireland is only $\$ 8.1$ billion.
} 
regressions of the form

$$
\log \left(\pi_{i}\right)=\beta_{0}+\beta_{1} \tau_{i}+\beta_{2} \ell_{i}+\beta_{3} k_{i}+u_{i}
$$

where $\pi_{i}$ is a measure of reported affiliate profit in country $i, \tau_{i}$ is a measure of the effective tax rate in country $i, \ell_{i}$ is a measure of labor used by affiliates in country $i, k_{i}$ is a measure of the physical capital stock used by affiliates in country $i$, and $u_{i}$ is a classical error term. This particular specification is from Hines and Rice (1994), which is estimated using data on the foreign affiliates of U.S. multinationals for 1982, drawn from the same data that we use.

In column 1 of Table III, we report an estimate of (10) using the 1982 data. We find a coefficient (a semi-elasticity) of -3.21 compared to -2.83 in Hines and Rice (1994). The different values reflect differences in our measure of profits and a slightly different sample of countries. In their model, the theoretical relationship between profits and taxes is

$$
\log \left(\pi_{i}\right)=\log \left(\rho_{i}\right)+c_{1} \tau_{i}+c_{2}
$$

where $\pi_{i}$ is the reported affiliate profit, $\rho_{i}$ is the profit derived from real economic activity, and $c_{1}$ and $c_{2}$ are constants. In the model, $\rho_{i}$ is derived from capital and labor, which leads to the $\ell_{i}$ and $k_{i}$ terms in (10). In contrast, we have directly computed $\rho_{i}$, so our theoretically consistent version of (10) is

$$
\log \left(\pi_{i}\right)-\log \left(\rho_{i}\right)=\beta_{0}+\beta_{1} \tau_{i}+u_{i}
$$

the estimates of which we report in the second column of Table III. We find a semi-elasticity with respect to tax rates of -5.15 . We view the similarity of our tax semi-elasticity - derived using no data on tax rates - to that from specifications that explicitly model profit shifting as a function of the tax rates to be an important consistency check on our results.

Since we have computed $\rho_{i}$ directly, we can further study the relationship between tax rates and profit derived from real economic activity. In column 3 in Table III, we regress $\rho_{i}$ on tax rates and measures of labor and capital inputs. Once we have removed the shifted profit from the reported profit, the tax rate is no longer significant. Our methodology appears to have removed the tax-motivated profit from the reported profit. 
TABLE III - Shifted profits and tax rates

\begin{tabular}{lccc}
\hline & $(1)$ & $(2)$ & $(3)$ \\
& $\log ($ unadj. profit $)$ & $\log \left(\frac{\text { unadj profit }}{\text { adj. profit }}\right)$ & $\log$ (adj. profit) \\
\hline Tax rate & -3.21 & -5.15 & 0.41 \\
& $(0.48)$ & $(1.02)$ & $(0.49)$ \\
Labor compensation & 0.44 & & 0.34 \\
& $(0.13)$ & & $(0.14)$ \\
Physical capital & 0.41 & & 0.64 \\
& $(0.13)$ & 2.62 & $(0.14)$ \\
Constant & 1.99 & $(0.38)$ & -1.94 \\
& $(0.41)$ & 0.31 & $(0.41)$ \\
Adj. R-squared & 0.92 & 56 & 0.95 \\
Observations & 56 & & 56 \\
\hline
\end{tabular}

Notes: Standard errors are reported in parentheses.

\subsection{Industry composition}

How is our adjustment distributed across industries? In Table IV, we report the adjustments by two-digit NAICS industry of the U.S. parent in $2016 .{ }^{26}$ We report an industry's adjustment as its share of the total adjustment and as its share of the industry's unadjusted value added. The industrial composition of the adjustment is consistent with the idea that firms use intangible assets to shift profits to low-tax jurisdictions.

The industry responsible for the largest contribution to the adjustment is NAICS sector 33, which includes the intellectual-property intensive electronics and computer manufacturing industries. NAICS sector 32-a subset of manufacturing - makes up 27 percent of the total adjustment. This industry is dominated by pharmaceuticals (a part of chemicals) and petroleum, which we have discussed above. (To avoid disclosure of confidential data, we cannot report the exact adjustments for these industries.) The pharmaceutical industry's profits are largely derived from its intellectual property, which provides ample opportunities for profit shifting. A major U.S. pharmaceutical company, for example, has licensed the manufacturing rights to some best-selling drugs to its Irish subsidiary (Bergin and Drawbaugh, 2015). NAICS sectors 51 and 54-which include software publishing, data processing and hosting, and computer system design - make up 16 percent of the aggregate

\footnotetext{
${ }^{26}$ The industry of the affiliate closest to the parent is often NAICS 55-holding companies - which is not very informative about the industrial composition of the sub-affiliates held by the affiliate holding company.
} 
TABLE IV - Adjustment by industry of U.S. parent, 2016

\begin{tabular}{lcc}
\hline & \multicolumn{2}{c}{ Adjustment (percent) } \\
\cline { 2 - 3 } Key industries & $\begin{array}{c}\text { Share of } \\
\text { total adjustment }\end{array}$ & $\begin{array}{c}\text { Share of } \\
\text { ind. value added }\end{array}$ \\
\hline 33 Computers, electrical equip., motor vehicles & 36.32 & 4.65 \\
32 Petroleum, chemicals, plastics, wood, paper & 27.01 & 5.30 \\
54 Legal, computer sys. design, scientific R\&D & 8.28 & 0.83 \\
51 Publishing, information, data processing & 8.12 & 1.17 \\
52 Finance, insurance & 5.58 & 0.53 \\
31 Food, textiles, apparel & 3.24 & 1.55 \\
21 Mining & 3.22 & 2.07 \\
53 Real estate, leasing & 2.31 & 0.13 \\
80 Other services, except government & 2.10 & 0.74 \\
22 Utilities & 1.94 & 0.90 \\
56 Administrative services & 1.53 & 0.38 \\
42 Wholesale trade & 1.20 & 0.15 \\
48 Transportation, warehousing & 0.93 & 0.22 \\
23 Construction & 0.28 & 0.05 \\
60 Education, health care & -0.13 & -0.01 \\
44 Retail trade & -0.29 & -0.04 \\
11 Agriculture, forestry, fishing, and hunting & -0.51 & -0.43 \\
55 Management of companies and enterprises & -0.56 & -0.22 \\
70 Arts, entertainment, accommodation & -0.58 & -0.10 \\
\hline
\end{tabular}

adjustment. As in the pharmaceutical industry, the "information" industry derives much of its profit from intangible assets and low marginal-production costs. NAICS sector 52 is responsible for 5.6 percent of the total adjustment. The foreign operations of the insurance industry, for example, are concentrated in Bermuda - a country whose corporate tax rate is zero.

The industries that are not significant contributors to the aggregate adjustment tend to be those in which it is difficult to uncouple the physical location of production from the point of sale. These industries include construction, transportation, education, health care, and other services.

\section{The implications of profit shifting}

In the previous section, we have shown how multinational profit shifting affects the measurement of aggregate output. In this section, we discuss how our adjustments to output 
Figure 5 - Trade balances

(A) Total trade balance

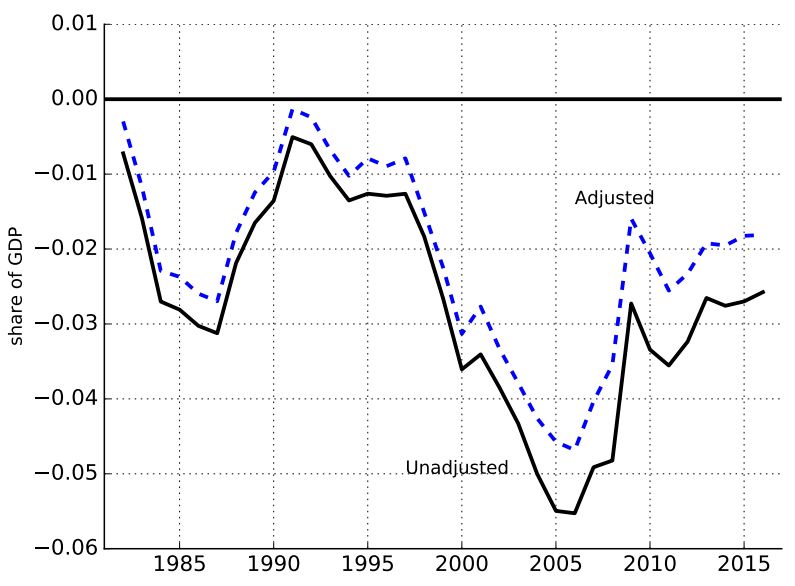

(B) Goods and services trade balances

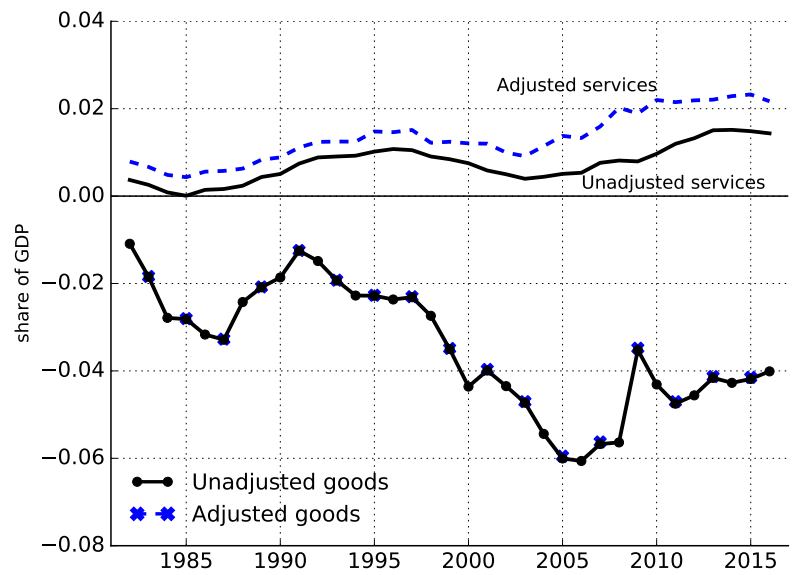

feed through to four key trends in the U.S. macroeconomic data. We begin with international variables and conclude with domestic measurement.

\subsection{External balances}

The income we reattribute to the United States is matched with a flow of exports from the United States to the rest of the world. In the aggregate, the effect of our adjustment on the U.S. trade balance, relative to GDP, can be seen in Figure 5A: The increase in exports makes the trade balance less negative. ${ }^{27}$ The effect of the adjustment (the gap between the solid and dashed lines in Figure 5A) is small throughout the 1980s and 1990s (less than 0.5 percent of GDP), but then grows rapidly after the turn of the 21st century. In 2016 , the unadjusted trade balance is -2.6 percent of GDP, and the adjusted trade balance is -1.8 percent of GDP.

Our assumption is that the reattributed income is the result of intangible assets created in the United States, so the offsetting exports would be classified as "charges for the use of intellectual property" and counted as a service export from the United States. In Figure 5B, we plot the trade balance for goods and services separately. Our adjustment does not change the goods trade balance, so the only differences between the adjusted and unadjusted goods trade-balance-to-GDP ratios are from changes to GDP in the adjusted measure. Our adjustment makes the services trade balance more positive, and, as before, the effect grows over time and especially rapidly in the 2000s. In 2016, the unadjusted services trade balance is 1.4 percent of GDP, and the adjusted services trade balance is 2.2

\footnotetext{
${ }^{27}$ The trade balance data are from Bureau of Economic Analysis (2021e).
} 
percent of GDP.

The adjustment to services trade, but not to goods trade, is the only result in which our assumption about the form of profit shifting plays a large role. If we had assumed all profit shifting was done through transfer pricing of intermediate goods between parents and affiliates, we would have only adjusted the goods balance and left the service balance unchanged. In reality, profit shifting occurs through both practices, but our evidence suggests that intangible assets are an important source of profit shifting. Since our approach is not directly informative of the profit shifting method, we make the simplifying assumption that it is all done through intangible assets.

The large effects of our adjustment on the trade balance raise a natural question: What is the effect on the current account? As is evident from equation (1), our adjustment decreases income on USDIA and increases exports of services by the same amount, leaving the current account unchanged. The current account does not change because we assume that interest payments between the parent and affiliates are unaffected by the adjustment. Bruner, Rassier, and Ruhl (2018) consider additional adjustments for interest payments and find a small, negative adjustment to the current account. ${ }^{28}$

\subsection{FDI returns}

Net international investment income for the United States is positive, even though the U.S. net international investment position is negative. Gourinchas and Rey (2007) show that this is the result of two factors: U.S.-owned foreign assets are riskier and less liquid than foreign-owned assets in the United States (a composition effect) and a rate of return differential within asset classes. Curcuru, Thomas, and Warnock (2013) argue that the rate of return differential is primarily driven by the rate of return differential on foreign direct investment and Wright and Zucman (2018) conclude that FDI return differentials are explained by the low foreign taxes paid by U.S. MNEs.

In the published data, U.S. MNEs have persistently earned higher returns on their foreign direct investment than foreign MNEs earn on their direct investment in the United States (Hausmann and Sturzenegger, 2007; McGrattan and Prescott, 2010). This can be seen in Figure 6A, in which the unadjusted return on USDIA is greater than the unadjusted return on FDIUS. The return on USDIA is computed as the after-tax income earned on U.S. foreign direct investment abroad divided by the stock of U.S.-owned foreign direct investment, measured at historical cost (Bureau of Economic Analysis, 2021f). The return

\footnotetext{
${ }^{28}$ Bruner, Rassier, and Ruhl (2018) examine the effects of profit shifting on other parts of the U.S. national accounts and balance of payments accounts. Their analysis is limited to a single year however, whereas here we examine the entire path of adjustments going back to 1982 .
} 
on FDIUS is computed analogously. From 1982 to 2016, the average return on USDIA is 11.7 percent and the average return on FDIUS is 4.6 percent. Starting in 2000, the average difference between the two closed to 1.2 percentage points, down from an average of 4.1 percentage points in 1982-2000.

FigURE 6 - Direct investment returns

(A) Returns on total direct investment

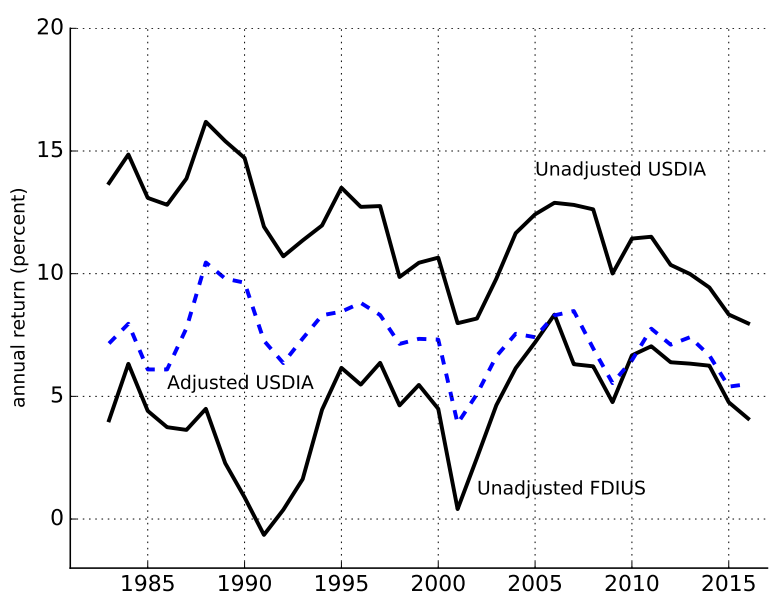

(B) Returns on direct investment by country type

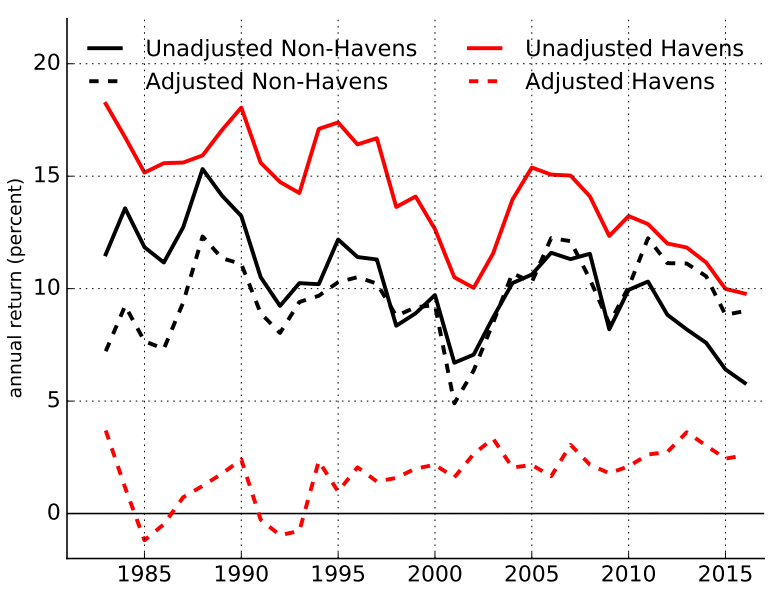

Several explanations of the return differential have been offered, including unmeasured assets - so-called dark matter - and asymmetries in risk, competition, and the distribution of firm ages. Profit shifting by U.S. MNEs is another possibility. By shifting profits to their foreign affiliates, U.S. MNEs boost the income earned on their foreign assets, and thus, their returns. We compute the adjusted rate of return on USDIA by subtracting our aggregate adjustment from reported income on USDIA and divide the result by the stock of U.S. foreign direct investment abroad. ${ }^{29}$ The adjusted return, plotted in Figure 6A, shifts the return on USDIA down bringing it close to the return on FDI in the United States. The average return on USDIA falls from 11.7 to 7.3 percent.

We can say more about the adjusted total return on USDIA by separating the host countries into tax haven countries and non-havens. ${ }^{30}$ In Figure 6B, we plot the adjusted and unadjusted returns for the two groups of countries. ${ }^{31}$ The adjusted return for nonhaven countries is lower than the unadjusted return in the early part of the sample and higher than the unadjusted return in the later part of the sample. The rate of return in the

\footnotetext{
${ }^{29}$ We lack the data to adjust the return on FDIUS. See Section 6 for details.

${ }^{30}$ Tax-haven countries are: Bahamas, Barbados, Bermuda, Costa Rica, Hong Kong, Ireland, Liechtenstein, Luxembourg, Netherlands, Panama, Singapore, Switzerland, and U.K. Islands-Caribbean.

${ }^{31}$ Data on direct investment positions by country are from Bureau of Economic Analysis (2022j) and direct investment income is from Bureau of Economic Analysis (2022i).
} 
haven countries falls significantly: The average return in haven countries falls from 14.2 percent to 1.7 percent.

Revisiting our earlier comparison of total FDI returns, it seems reasonable to compare the return on FDIUS (the United States is not a tax haven) to the adjusted return on non-haven countries. The average adjusted return on non-haven countries is 9.6 percent compared to the average return on FDIUS of 4.6 percent. This suggests a more nuanced interpretation of the rate-of-return puzzle. The difference in total returns is largely eliminated by adjusting for profit shifting, but among non-haven countries, the United States continues to earn a premium on its foreign direct investments.

Our simple adjustment raises many questions: What industries and countries are most affected? How do returns on U.S. MNE domestic assets compare to the adjusted return on USDIA? How do we adjust the stocks of FDI for profit shifting? Answering these questions requires digging deeper into the data. Further measurement issues arise and stocks of FDI at disaggregated levels are difficult to construct. We leave these interesting questions to future research.

\subsection{Productivity}

A striking feature of the U.S. data is the slowdown in aggregate productivity growth that began in or around 2004. ${ }^{32}$ Our adjustment increases the growth rate of U.S. GDP between 1998 and 2010. Our adjustment does not change measured labor input, so faster GDP growth will imply faster labor productivity growth. ${ }^{33}$

We follow Fernald (2015) in constructing labor productivity as output per hour worked in the domestic business sector. ${ }^{34}$ The unadjusted labor productivity growth rate over the entire period averages 2.05 percent per year. This period is often broken into three subperiods that displayed distinct growth patterns: 1982-1994, 1994-2004, and 2004-2016. The unadjusted labor productivity growth rate averaged 1.84 percent per year from 1982 to $1994,3.08$ percent per year from 1994 to 2004, and fell to 1.41 percent per year in the

\footnotetext{
${ }^{32}$ Productivity growth has slowed down in many countries. Since our adjustment does not change global output, it cannot be the source of the slowdown in every country. The adjustment in the United States is particularly large, so we are studying its impact on productivity.

${ }^{33}$ Our adjustments do not change the measured U.S. capital stock because, in practice, intrafirm sales or transfers of intellectual property are not deducted under the perpetual inventory method, so adjusted TFP will change in the same way as labor productivity. When a parent transfers an intangible asset to an affiliate, we assume the economic ownership of that intangible asset does not change - and neither does the capital stock.

${ }^{34}$ Data on hours worked are from (Bureau of Economic Analysis, 2021h), (Bureau of Labor Statistics, 2022), and (Bureau of Labor Statistics, 2021a).
} 
last period (2004-2016). We report cumulative and average annual productivity growth rates in Table $\mathrm{V}$.

FIGURE 7 - Aggregate cumulative labor productivity growth

(A) Adjusted and unadjusted

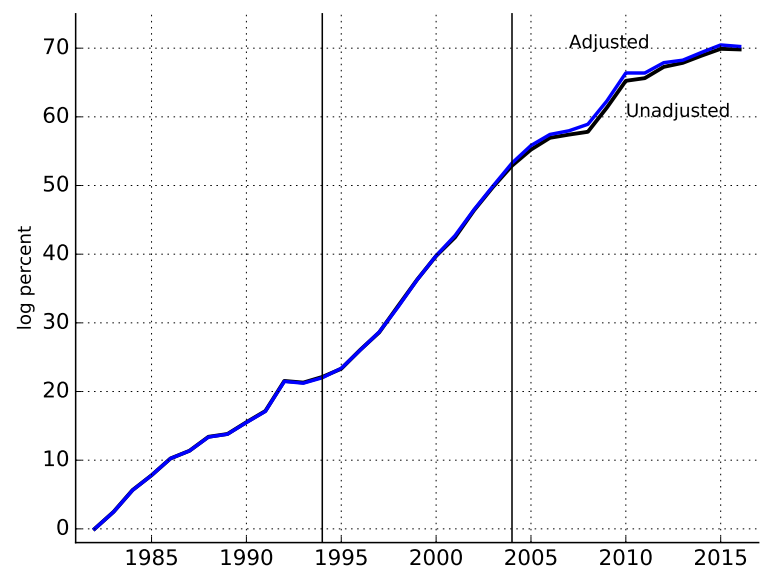

(B) Difference between adjusted and unadjusted

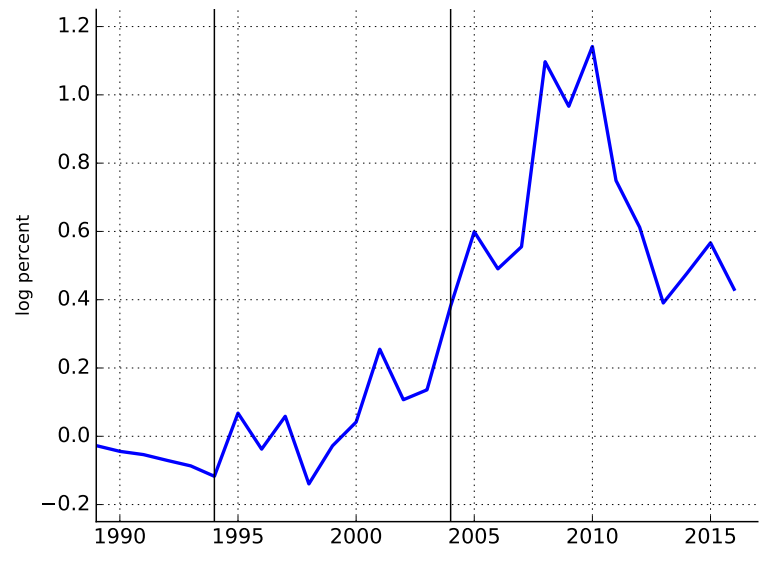

We construct adjusted labor productivity by dividing our adjusted measure of business sector value added (Figure 1B) by the same hours-worked series we used in constructing unadjusted labor productivity. In Figure 7A, we plot the cumulative growth of adjusted and unadjusted labor productivity. Unadjusted aggregate labor productivity grew by 69.8 log percentage points over the period. Our adjustment increases cumulative productivity growth to 70.2 percent. From Figure 7A, it is clear that the adjustment does not affect aggregate productivity in a substantial way until the 1990s, with most of the adjustment occurring after 2000.

In Figure 7B, we plot the difference between the adjusted and unadjusted cumulative growth rates for 1990-2016. In the figure, we see that the effect of offshore profit shifting peaked in 2010, at which time it added about 1.1 percentage points to cumulative productivity growth. Post-2010, the adjustment grows more slowly than GDP and the impact on aggregate productivity growth falls. From 2004-2010, the adjustment grew faster than GDP and added 13 basis points to annual productivity growth rates. From 2010 onward, the adjustment grew slower than GDP and lowered annual growth rates by 12 basis points.

How does offshore profit shifting affect our understanding of the productivity slowdown? Profit shifting was at work during both the productivity speed up and the slow down, so the answer is not obvious. As reported in Table V, our adjustment adds five basis points to annual growth rates during the fast-growth period and almost nothing in the slow-growth period. This means that the average annual growth rate of measured productivity falls 
TABLE V - Labor productivity growth rates (log percent)

\begin{tabular}{cccccc}
\hline & \multicolumn{2}{c}{ Cumulative growth rate } & & \multicolumn{2}{c}{ Average annual growth rate } \\
\cline { 5 - 6 } & Unadjusted & Adjusted & & Unadjusted & Adjusted \\
\hline $1982-2016$ & 69.8 & 70.2 & & 2.05 & 2.07 \\
$1982-1994$ & 22.1 & 22.0 & & 1.84 & 1.83 \\
$1994-2004$ & 30.8 & 31.3 & & 3.08 & 3.13 \\
$2004-2016$ & 16.9 & 17.0 & & 1.41 & 1.41 \\
$2004-2010$ & 12.4 & 13.1 & & 2.06 & 2.19 \\
$2010-2016$ & 4.6 & 3.9 & & 0.76 & 0.64 \\
\hline
\end{tabular}

to about 46 percent of that in the fast-growth period $(1.41 / 3.08=0.46)$ in the unadjusted data and by a bit more $(1.41 / 3.13=0.45)$ in the adjusted data. In the aggregate, profit shifting makes the measured productivity slowdown a bit worse.

\section{Productivity and R\&D}

Our findings in Section 4.4 support the idea that intangible assets are an important channel for profit shifting. Attributing the return to intangible capital correctly is likely to make a bigger difference in industries in which intangible capital is more important. To investigate this hypothesis, we construct adjusted productivity measures for industries grouped by their R\&D intensities. We take R\&D intensity to be a proxy for the importance of intangible assets (e.g., patents, algorithms) in production. ${ }^{35}$

We use the survey data to calculate R\&D intensity at the enterprise level - the U.S. parent and all of its foreign affiliates. We calculate R\&D intensity by dividing enterpriselevel R\&D expenditures, aggregated across all available years, by enterprise-level sales to unaffiliated parties, aggregated across all available years. We consider an enterprise to be $R \mathscr{E} D$ intensive if its $\mathrm{R} \& \mathrm{D}$ intensity is at or above the 75 th percentile. In most cases, R\&Dintensive enterprises include U.S. parents and foreign affiliates classified into industries that are considered to be R\&D intensive as defined in Moylan and Robbins (2007). ${ }^{36}$

In Figure 8A, we plot, as a share of unadjusted value added, the adjustments for R\&Dintensive and non-R\&D-intensive industries. The adjustments for R\&D-intensive industries grow rapidly during the 1990s and early 2000s before decreasing, and then rebounding,

\footnotetext{
${ }^{35}$ Motivated by Bloom, Sadun, and Van Reenen (2012) and Fernald (2015), we also split our sample into IT-using/non-IT-using and IT-producing/non-IT-producing firms. The differences between these groups of firms are smaller than when we split firms by R\&D intensity. Results using these other classifications are reported in the online appendix.

${ }^{36}$ Employment by industry data are from Bureau of Economic Analysis (2021h) and Bureau of Labor Statistics (2021b).
} 
FiguRE 8 - Adjustments and cumulative labor productivity growth, by R\&D intensity

(A) Adjustments

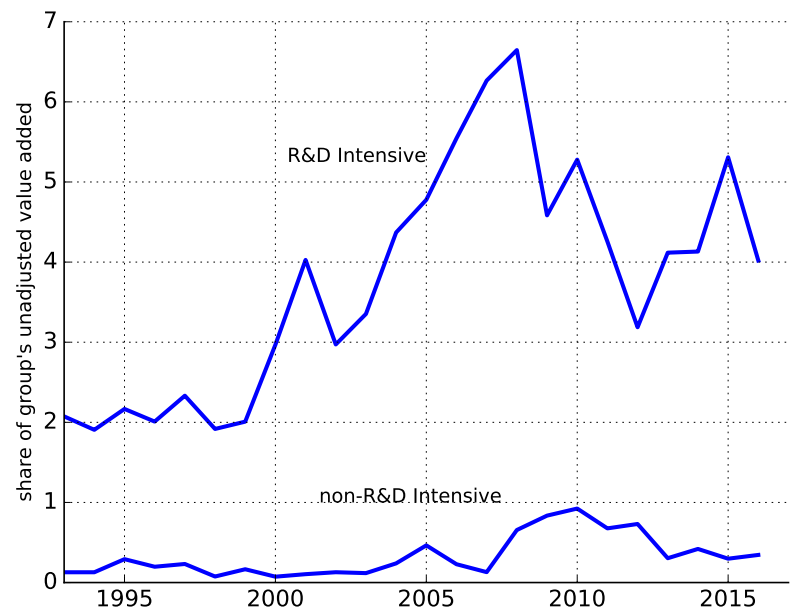

(B) Cumulative productivity growth difference

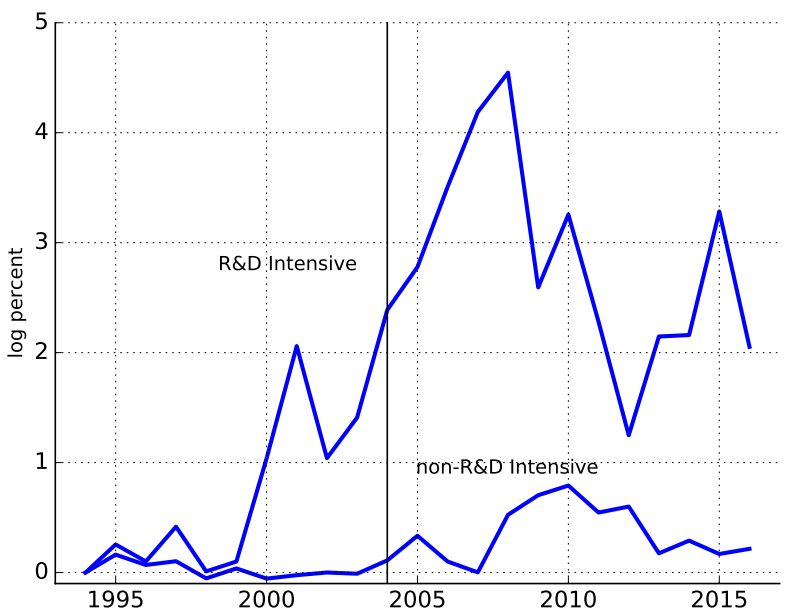

post-2008. The adjustments for R\&D-intensive enterprises as a share of value added are substantially larger than those for non-R\&D-intensive enterprises, with the adjustment for R\&D-intensive enterprises peaking in 2008 at 6.6 percent of nominal value added. Note that the adjustment is 3.9 times as important in $R \& D$ intensive industries as it is in the aggregate (Figure 1A). Profit shifting is concentrated in this group of R\&D-intensive firms.

The impact of our adjustments on productivity growth by R\&D intensity is evident in Figure 8B, in which we plot the difference in cumulative labor productivity growth between the adjusted and unadjusted series (this is the analogue of Figure 7B). From 1994 to 2016, adjusting for offshore profit shifting in the R\&D-intensive industries adds $2.1 \mathrm{log}$ points to cumulative growth but only $0.2 \mathrm{log}$ points in non-R\&D-intensive industries. As we observed in the aggregate data, the largest effects on productivity growth occurred in the late 1990s and early 2000s (Table VI). ${ }^{37}$

\section{Increasing productivity dispersion and $R \& D$}

There is another pattern in Table VI that is hard to miss: labor productivity in R\&Dintensive industries has grown much faster - by a factor of 3 -relative to non-R\&D-intensive industries during the entire sample period. Furthermore, as seen in Figure 9, the productivity gap has widened at an accelerating rate up until the Great Recession, with R\&Dintensive industries growing 3 times faster between 1982 and 1994 and 4 times faster be-

\footnotetext{
${ }^{37}$ Nominal value added by industry is from Bureau of Economic Analysis (2019) and Bureau of Economic Analysis (2021i). The price indexes by value added are from Bureau of Economic Analysis (2021a) and Bureau of Economic Analysis (2021b).
} 
TABLE VI - Cumulative Labor Productivity Growth, by R\&D (log percent), 1994-2016

\begin{tabular}{lcccccc}
\hline Data range & $82-94$ & $94-16$ & $94-04$ & $04-16$ & $04-08$ & $08-16$ \\
\hline R\&D intensive & & & & & & \\
$\quad$ Adjusted & 53.4 & 106.4 & 73.5 & 32.9 & 21.6 & 11.3 \\
$\quad$ Unadjusted & 53.3 & 104.3 & 71.1 & 33.3 & 19.4 & 13.8 \\
$\quad$ Non-R\&D intensive & & & & & & \\
$\quad$ Adjusted & 18.6 & 32.0 & 21.1 & 10.8 & 2.5 & 8.3 \\
$\quad$ Unadjusted & 18.7 & 31.8 & 21.0 & 10.7 & 2.1 & 8.6 \\
\hline
\end{tabular}

FigURE 9 - Cumulative productivity growth by R\&D intensity

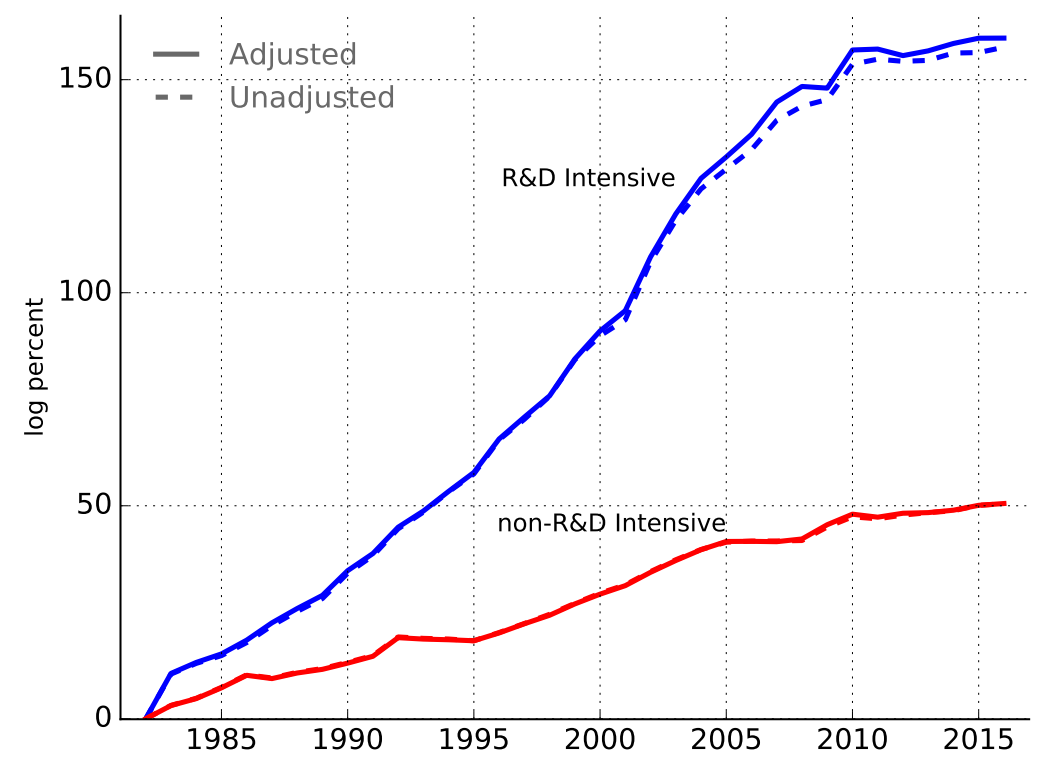

tween 1994 and 2008. Some recent papers have documented rising productivity dispersion across firms in many developed economies since the turn of the 21st century (e.g., Decker, Haltiwanger, Jarmin, and Miranda (2016) for the United States and Andrews, Criscuolo, and Gal (2016) for OECD countries). Figure 9 extends these results by documenting productivity divergence over a longer time horizon that begins in 1982. It also shows that R\&D intensity was an important differentiator between industries whose productivity grew rapidly and those that lagged behind. Finally, and more importantly, it shows that the slow growth in U.S. aggregate productivity was primarily due to the sluggish growth of non-R\&D-intensive industries - 1.7 percent per year between 1982 and 2010 - while R\&Dintensive industries grew at a remarkably fast pace of 5.6 percent per year. ${ }^{38}$ This observa-

\footnotetext{
${ }^{38}$ This pattern for the United States is consistent with the findings in Andrews, Criscuolo, and Gal (2016) for other OECD countries.
} 
tion suggests that understanding the factors driving the productivity divergence could be key for understanding the slowdown in aggregate productivity observed in many countries. A fuller analysis of these patterns is beyond the scope of this paper, so we leave it for future research.

\section{Further implications for the measured slowdown}

Under the accepted dating convention, our adjustments do not affect the aggregate productivity slowdown - the adjustment speeds up growth both before and after 2004. We could, however, also ask: Does our adjustment change the timing of the slowdown? A series of papers (e.g., Anzoategui, Comin, Gertler, and Martinez, 2019; Garga and Singh, 2020) has hypothesized that the productivity slowdown is an endogenous response to the recession that began in 2007. Fernald (2015) and others, however, have argued that the slowdown started before the recession. In Figure 7A, the adjusted productivity series pulls away from the unadjusted series and continues to grow after 2004. Does this push the beginning of the slowdown past 2004 ?

In the online appendix, we plot the rolling average productivity growth rates for the adjusted and unadjusted data. We do not find strong evidence that the timing of the decline in aggregate productivity growth rates changes after the adjustment: The inflection points of the two series are the same. It is worth noting, however, that the slowdown in the R\&D-intensive industries occurred later, in or around 2007. This suggests that the innovation-driven mechanism in Garga and Singh (2020) may be at work, but, again, we do not find strong evidence that the slowdown occurs later in the adjusted data.

Our adjustments result from profit shifting within MNEs, which is only one source that can affect economic measurement as an explanation for the productivity slowdown. Syverson (2017) starts from the basic quantitative fact that a reversal of the productivity slowdown would have required measured GDP in 2015 to have been 17 percent higher: $\$ 3$ trillion. Thus, even a modest fraction of the productivity slowdown explained by measurement would imply hundreds of billions of dollars missing from GDP. While our findings support up to $\$ 157$ billion of unmeasured GDP, Syverson (2017) explains four straight-forward reasons that would still challenge the measurement hypothesis as a single explanation for the productivity slowdown. Byrne, Fernald, and Reinsdorf (2016) quantify a number of possible areas of measurement-including information technology, intangibles, "free" digital services, and globalization - that may explain some of the productivity slowdown, and they also conclude that the measurement hypothesis cannot be a single explanation for the productivity slowdown.

While our study focuses on output measurement, efforts to improve other core economic 
statistics that affect productivity measurement, such as price indices, have been launched in response to the Boskin Commission (Boskin, Dulberger, Gordon, Griliches, and Jorgenson, 1996), which found a 1.1 percent bias in the Consumer Price Index. Recent academic studies such as Aghion, Bergeaud, Boppart, Klenow, and Li (2019) explore nuances for quality improvements in price measurement that may have been unknown to the Boskin Commission and conclude that resulting missing productivity growth does not explain the sharp slowdown in growth since 2005. Moulton (2018) summarizes changes made by statistical agencies since the Boskin Commission and finds that the bias in the CPI has been reduced to about 0.85 percent. Moulton (2018) concludes there is no evidence that the overall bias has worsened since 1996. Thus, our results for productivity are consistent with these related studies on economic measurement as an explanation for the productivity slowdown.

\subsection{Labor share of income}

A well-established empirical regularity during much of the 20th century is the lack of a time trend in labor's share of aggregate income. This relationship appeared so robust that it became one of Kaldor's balanced growth facts and a key feature that macroeconomic models aimed to match. A number of recent studies, however, find that the labor share has been declining in recent decades - especially since the early 2000s (Autor, Dorn, Katz, Patterson, and Van Reenen, 2020; Elsby, Hobijn, and Sahin, 2013; Karabarbounis and Neiman, 2014). The decline in the labor share has led to a surge in interest in the measurement of the labor (and capital) share. Our adjustment to GDP has implications for this measurement issue as well. The income we reattribute to the United States is part of domestic capital income (corporate profits), which has the effect of reducing the labor share and raising the capital share.

To quantify the magnitude of this effect, in Figure 10A, we plot the unadjusted gross labor share of income for corporate business: employee compensation divided by gross value added. ${ }^{39}$ We also plot the adjusted gross labor share: employee compensation divided by the sum of gross value added and our aggregate adjustment. As can be anticipated from our previous findings, the adjustment grows over time and accelerates in the 2000s. The unadjusted gross labor share fell from 0.647 in 2001 to 0.573 in 2016, for a decline of 7.5 percentage points, whereas the adjusted labor share fell from 0.641 to 0.565 during the same time, for a decline of 7.5 percentage points. Profit shifting has its largest effect in

\footnotetext{
${ }^{39}$ This is one of the measures used by Bridgman (2017), who also demonstrates that the treatment of depreciation and taxes affects the measured labor share. Our adjustment yields similar results regardless of the measure considered.
} 
Figure 10 - Labor share in the United States

(A) Aggregate

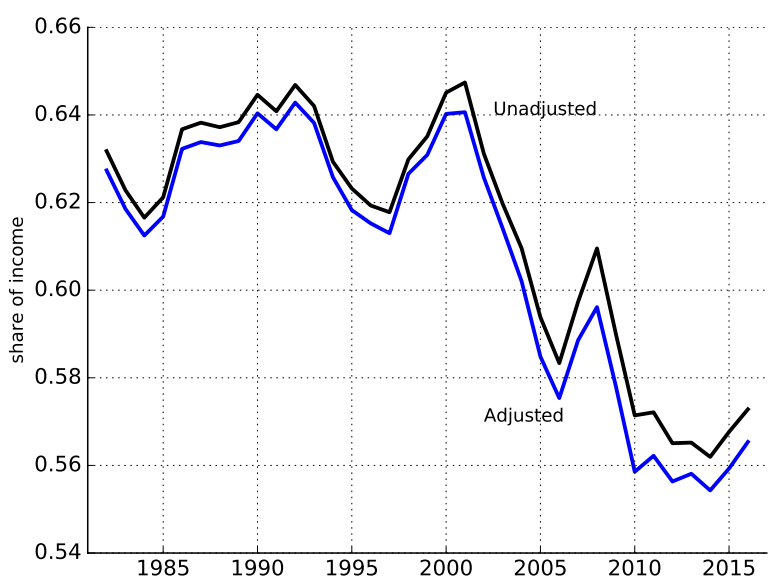

(B) Selected industries

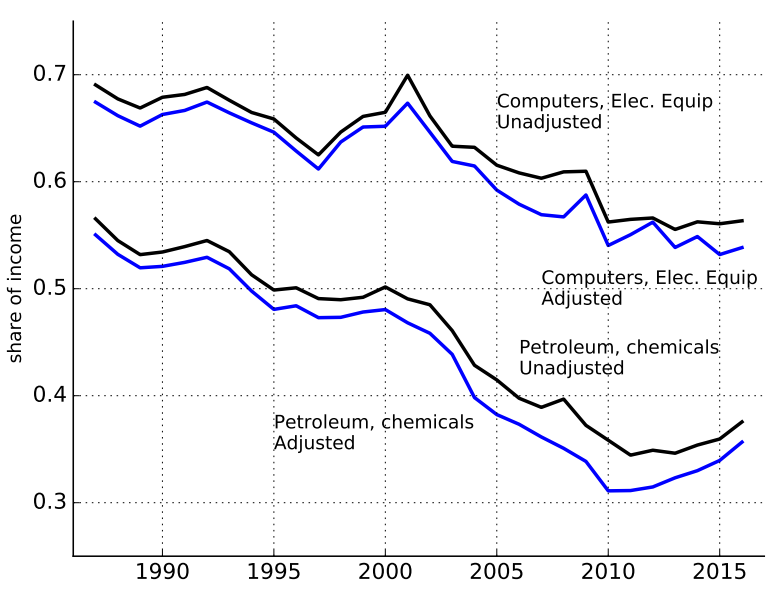

Notes: "Computers, Elec. Equip" is the "Computers, electrical equipment, motor vehicles" (NAICS 33) component of manufacturing. "Petroleum, chemicals" is the "Petroleum, chemicals, plastics, wood, paper" (NAICS 32) component of manufacturing. Complete definitons of all industry groups are in the online appendix.

2010, where the adjusted labor share is 1.3 percentage points lower than the unadjusted share. ${ }^{40}$

The adjustment in the aggregate labor share of income is driven by a handful of industries. We plot the industry-level labor shares in Figure 10B for the "Computers, electrical equipment, and motor vehicles" grouping and the "Petroleum, chemicals, plastics, wood, and paper" grouping - these two industries had the largest adjustments in $2016 .{ }^{41}$ We plot

\footnotetext{
${ }^{40}$ Cooper, McClelland, Pearce, Prisinzano, Sullivan, Yagan, Zidar, and Zwick (2016) study significant upward trends in pass-through business income since 1980. They use tax data for 2011 to identify who owns partnerships and S-corporations and whose income may be interpreted as labor income rather than capital income, but they do not estimate a measure of income attributable to individuals through partnership or S-corporation income. They note, however, that in 2011, 25.6 percent of business income is attributable to partnerships and 16.5 percent is attributable to S-corporations. Moreover, they find that the percentage of partnership income that accrues to individuals is 31.5 percent and to S-corporations is 3.4 percent. All S-corporation income accrues to individuals. Based on business income of $\$ 2.6$ trillion in 2011, these percentages imply partnership income attributable to individuals is $\$ 232.3$ billion ( $\$ 2.6$ trillion x 0.256 $\mathrm{x}(0.315+0.034)$ and S-corporation income attributable to individuals is $\$ 429.0$ billion $(\$ 2.6$ trillion $\mathrm{x}$ $0.165)$ for a total of $\$ 661.3$ billion that could be interpreted as labor income rather than capital income. In 2011, our estimated adjustment for profit shifting is $\$ 152.1$ billion, so the net upward effect on labor income would be (\$661.3-\$152.1=) $\$ 509.2$ billion under this alternative interpretation, which would imply an increase in the labor share of income for 2011 from 0.572 to 0.631 . While the income is attributable to individuals for tax purposes, all business income earned by partnerships and S-corporations would continue to be classified as capital income in the business sector rather than labor income in the household sector in the U.S. national accounts, so this alternative interpretation would not affect labor shares under current practice.

${ }^{41}$ Gross output and compensation data by industry are from Bureau of Economic Analysis (2021c) and
} 
the labor shares for all of our industry groupings in the online appendix. For 2000-2016, the average labor share in the Petroleum group is 2.9 percentage points lower after adjusting for profit shifting with the largest difference between the two series occurring in 2010 at 4.7 percentage points. In the Computers group, the average labor share is 2.1 percentage points lower with the largest difference occurring in 2008 at 4.2 percentage points.

\section{Foreign MNEs in the United States}

Although the primary focus of this paper is the apportionment of the worldwide profits of U.S.-owned MNEs, profit shifting by foreign-owned MNEs that operate affiliates in the United States can also affect the measurements studied in the previous section. If foreignowned MNEs shift profit out of the United States, this will reduce U.S. GDP and income on FDIUS (see (1) for the accounting identity).

Ideally, we could apply the methodology that we used for U.S.-owned MNEs to foreignowned MNEs operating in the United States and arrive at a measure of the profit shifting by foreign MNEs. Data availability, however, poses difficulties. Whereas the BEA direct investment surveys cover the worldwide operations of U.S.-owned MNEs, BEA does not have the legal authority to collect data on the worldwide operations of foreign-owned MNEs that own U.S. affiliates. Creating a data set comparable to the one we use to study U.S. MNEs requires combining BEA data on the U.S. operations of foreign MNEs with data on the foreign MNEs' worldwide operations from a commercial data set such as Bureau van Dijk's Orbis. A particularly challenging aspect of this work is creating a match between companies in the two data sets. A common numeric identifier does not exist in the two data sets, so the linking must be done by name matching, which, because of inconsistencies and ambiguities in company names, is imperfect and time consuming.

Nevertheless, to give a sense of the potential significance of profit shifting by foreignowned U.S. businesses, we develop a partial link between the BEA and Orbis data sets for 2008, 2012, and 2015. Given our finding that R\&D-intensive firms are most affected by profit shifting, we construct a data set of large technology-intensive, foreign-owned U.S. businesses containing the data needed to conduct an apportionment exercise. These businesses account for about 40 percent of R\&D spending by foreign-owned U.S. businesses and 12 percent of employment in all foreign-owned U.S. businesses. The scope of our data set is summarized in Table VII and more detail on the construction of the data set is in the online appendix.

Bureau of Economic Analysis (2021d). Data availability on value added by industry limit our sample to 1987 onward. 
TABLE VII - Profit shifting

\begin{tabular}{ccccccc}
\hline & \multicolumn{4}{c}{ FDIUS } & & USDIA \\
\cline { 2 - 4 } $\begin{array}{c}\text { Number of } \\
\text { firms }\end{array}$ & $\begin{array}{c}\text { Share of } \\
\text { R\&D spending }\end{array}$ & $\begin{array}{c}\text { Share of } \\
\text { employment }\end{array}$ & $\begin{array}{c}\text { Est. shifted } \\
\text { profit (bil.) }\end{array}$ & & $\begin{array}{c}\text { Est. shifted } \\
\text { profit (bil.) }\end{array}$ \\
\hline 2008 & 137 & 0.45 & 0.13 & 2.1 & 182.2 \\
2012 & 136 & 0.43 & 0.13 & 12.3 & \\
2015 & 127 & 0.32 & 0.11 & 3.5 & & 144.0 \\
\hline
\end{tabular}

Notes: The column labeled "Share of R\&D spending" is the share of R\&D spending by foreign-owned U.S. businesses, and the column labeled "Share of employment" is the share of total U.S. employment in foreign-owned U.S. businesses.

In the data set we have been able to construct, we find evidence that foreign-owned MNEs operating in the United States are shifting profits out of the United States. In Figure 11, on the vertical axis, we plot the reported U.S. share of worldwide profits for each foreign-owned MNE in our sample. On the horizontal axis, we plot the apportionment weight for the U.S. operations of each foreign-owned MNE. ${ }^{42}$ In our methodology, if there was no profit shifting, the two measures would fall on the 45-degree line. Since each point underlying the figure is data from an individual foreign-owned MNE operating in the United States, to maintain the confidentiality of the survey data, we cannot show the scatter plot. Instead, we report the locally-weighted central tendency of the scatter plot (Lowess smoothed values) and the fitted values from an ordinary least squares regression.

In 2008 (not reported) and 2012, we find the U.S. share of profits is significantly below the 45-degree line - particularly for foreign-owned MNEs with operations concentrated in the United States. The locally-weighted central tendency of the scatter plot (Figure 11) suggests that, for foreign-owned businesses with less than 20 percent of their worldwide production attributed to their U.S. operations, their U.S. profits are roughly proportional to their attributed U.S. production. However, the U.S. profits of foreign-owned businesses with 20 percent or more of their worldwide production attributed to the United States are significantly understated relative to their attributed production in the United States.

In the 2015 data, we find less evidence of foreign-MNEs shifting profit out of the United States (Figure 11B). In this case, the firms in our sample have U.S. profit shares that are roughly proportional to their production shares. This result is consistent with the increased efforts by revenue authorities in the United States to deter profit shifting, but given the incomplete nature of our data, it is difficult to know the extent to which this result reflects a reduction in profit shifting by foreign MNEs or an artifact of our sample.

\footnotetext{
${ }^{42}$ We use employee compensation and net PPE - equally weighted - as apportionment factors.
} 
FiguRE 11 - Foreign-owned MNEs operating in the United States

(A) 2012

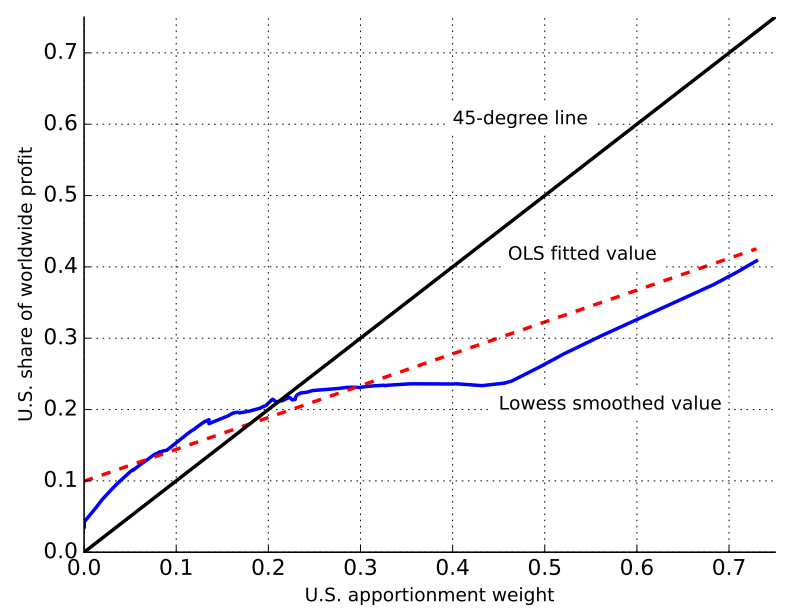

(B) 2015

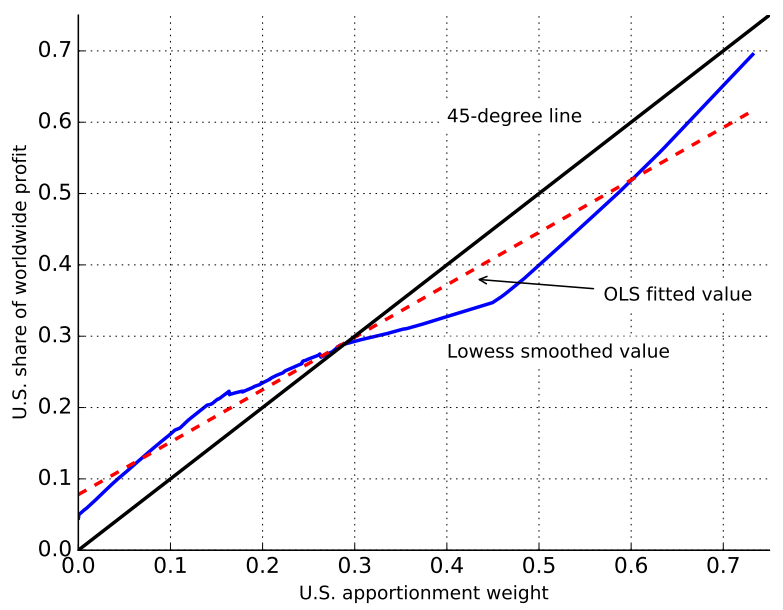

Altogether, if the profits of these foreign-owned businesses were reattributed according to the weighted apportionment factors, their U.S. profits (and U.S. GDP) would have been $\$ 2.1$ billion higher in 2008, $\$ 12.3$ billion higher in 2012 , and $\$ 3.5$ billion higher in 2015 . It is difficult to judge the magnitude of these figures given the small size of our data set, but it does suggest that foreign-owned MNEs are shifting profit out of the United States.

Overall, our analysis, incomplete as it is, suggests that profits of foreign-owned MNEs were being shifted out of the United States. This implies that our findings from the U.S. MNE data (Section 4) are likely the lower bounds of profit shifting adjustment.

\section{Concluding remarks}

Using firm-level data on U.S. MNEs, we find that, on average, 38 percent of income generated from U.S. foreign direct investment abroad is reattributable to U.S. GDP. Adding this shifted profit to value added increases U.S. GDP and decreases the trade deficit, the rate of return on USDIA, and labor's share of income. Profit shifting is concentrated in industries and firms with significant R\&D expenditures. In our sample, profit shifting reached its peak in 2010, but remains still a significant issue. In 2016, official domestic businesssector value added in the United States was, on average, more than 1 percent - about $\$ 140$ billion-lower than our adjusted measure.

We also examine profit shifting by the U.S. subsidiaries of foreign MNEs. The data used to analyze these companies are not as complete as the BEA survey data that we use for U.S. MNEs, so we are not able to provide a definitive assessment. That said, our 
preliminary findings - especially Figure 11-suggest a similar pattern. Further work on this topic is warranted.

\section{References}

Aghion, P., A. Bergeaud, T. Boppart, P. J. Klenow, and H. Li (2019): "Missing growth from creative destruction," American Economic Review, 109(8), 2795-2822.

Albertus, J. F. (2019): "The direct investment income puzzle," https://dx.doi.org/ $10.2139 / \operatorname{ssrn} .3248774$.

Andrews, D., C. Criscuolo, and P. Gal (2016): "The Best versus the Rest: The Global Productivity Slowdown, Divergence Across Firms and the Role of Public Policy," OECD Productivity Working Papers 05, OECD.

Anzontegui, D., D. Comin, M. Gertler, And J. Martinez (2019): "Endogenous technology adoption and R\&D as sources of business cycle persistence," American Economic Journal: Macroeconomics, 11(3), 67-110.

Autor, D., D. Dorn, L. F. Katz, C. Patterson, and J. Van Reenen (2020): "The fall of the labor share and the rise of superstar firms," Quarterly Journal of Economics, 135(2), 645-709.

Avi-Yonah, R. S. (2010): "Between formulary apportionment and the OECD guidelines: a proposal for reconciliation," World Tax Journal, 2(1), 3-18.

Avi-Yonah, R. S., And I. Benshalom (2011): "Formulary apportionment — myths and prospects," World Tax Journal, 3(3), 371-399.

Avi-Yonah, R. S., And K. A. Clausing (2007): "Reforming corporate taxation in a global economy: a proposal to adopt formulary apportionment," Hamilton Project Discussion Paper 2007-08, Brookings Institution.

Bergin, T., and K. Drawbaugh (2015): "How Pfizer has shifted U.S. profits overseas for years," Reuters, November 16.

Bloom, N., R. Sadun, and J. Van Reenen (2012): "Americans do IT better: U.S. multinationals and the productivity miracle," American Economic Review, 102(1), $167-201$.

Blouin, J., And L. A. Robinson (2020): "Double counting accounting: How much profit of multinational enterprises is really in tax havens?," https://dx.doi.org/10.2139/ssrn.3491451.

Boskin, M. J., E. R. Dulberger, R. J. Gordon, Z. Griliches, and D. Jorgenson (1996): "Final report of the advisory commission to study the consumer price index," Committee on Finance, U.S. Senate, William V. Roth Jr., Chairman. 104th Congress, 
2nd Session, S. Prt., 104-72. Washington, D.C.: Government Printing Office.

Bridgman, B. (2017): "Is labor's loss capital's gain? Gross versus net labor shares," Macroeconomic Dynamics, pp. 1-18.

Bruner, J., D. G. Rassier, And K. J. Ruhl (2018): "Multinational profit shifting and measures throughout economic accounts," mimeo.

Bureau of Economic Analysis (2019): "Value added by industry, 19821997," Release date: October 29, 2019. https://apps.bea.gov/iTable/ iTable.cfm?reqid=147\&step=51\&isuri=1\&startyear=1982\&table_list= 1\&endyear=1\&valuationtype=b\&thetable=1\&codelist=22r, gdpva, pvtva, $11 \mathrm{va}$ , 111cava, 113ffva, 21va, 211va, 212va, 213va, 22va, 23va, 31gva, 33dgva, 321va , 327va, 331va, 332va, 333va, 334va, 335va, 3361mvva, 3364otva, 337va, 339va , 31ndva, 311ftva, 313ttva, 315alva, 322va, 323va, 324va, 325va, 326va, 42va , 44rtva , 441va, 445va, 452va, 4a0va , 48twva, 481va, 482va, 483va, 484va, 485va ,486va , 487osva , 493va, 51va, 511va, 512va, 513va, 514va , fireva, 52va, 521civa , 523va, 524va, 525va, 53va, 531va, vahs, vaore, 532rlva, prof va, 54va, 5411va , 5415va, 5412opva, 55va, 56va, 561va, 562va, 6va, 61va, 62va, 621va, 622hova , 622va, 623va, 624va, 7va, 71va, 711asva, 713va, 72va, 721va, 722va, 81va, gva , gfva, gfgva, vagfgd, vagfgn, gfeva, gslva, gslgva, gsleva, adndadnd, pgoodva , pservva, ictva.

(2021a): "Chain-type price indexes for value added by industry, 19821997," Release date: November 16, 2021. https://apps.bea.gov/iTable/ iTable.cfm?reqid=147\&step=51\&isuri=1\&startyear=1982\&table_list= 11\&endyear=1\&valuationtype=b\&thetable=1\&codelist=22r, gdpva, pvtva, $11 \mathrm{va}$ , 111cava, 113ffva, 21va, 211va, 212va, 213va, 22va , 23va , 31gva , 33dgva , 321va , 327va, 331va, 332va, 333va, 334va, 335va, 3361mvva, 3364otva, 337va, 339va , 31ndva , 311ftva, 313ttva, 315alva, 322va, 323va, 324va, 325va, 326va, 42va , 44rtva , 441va, 445va, 452va, 4a0va , 48twva, 481va, 482va, 483va , 484va, 485va , 486va , 487osva, 493va, 51va, 511va, 512va, 513va, 514va, fireva, 52va, 521civa , 523va, 524va, 525va, 53va, 531va, vahs, vaore, 532rlva, prof va, 54va, 5411va , 5415va, 5412opva, 55va, 56va, 561va, 562va, 6va, 61va, 62va, 621va, 622hova , 622va, 623va, 624va, 7va, 71va, 711asva, 713va, 72va, 721va, 722va, 81va, gva ,gfva, gfgva, vagfgd, vagfgn, gfeva, gslva, gslgva, gsleva, adndadnd, pgoodva , pservva, ictva.

(2021b): "Chain-type price indexes for value added by industry, 1997-2016," Release date: September 30, 2021. https://apps.bea.gov/ iTable/iTable.cfm?reqid=150\&step=3\&isuri=1\&table_list=11\&series= 
a\&first_year=1997\&columns=ii\&scale=-99\&last_year=2016\&categories= gdpxind\&thetable $=$ \&rows $=22 r$.

(2021c): "Components of value added by industry, 1987-1997," Release date: November 16, 2021. https://apps.bea.gov/iTable/ iTable.cfm?reqid=147\&step=51\&isuri=1\&startyear=start\&table_list= 6\&endyear=1\&valuationtype=b\&thetable=1\&codelist=22r, gdpva, gdpcomp , gdptxpixsub, gdpgos , pvtva, pvtcomp, pvttxpixsub, pvtgos , 11va, 11 comp ,11txpixsub, 11gos, 111cava, 111cacomp, 111catxpixsub, 111cagos, 113ffva ,113ffcomp, 113fftxpixsub, 113ffgos , 21va, 21 comp, 21txpixsub, $21 \mathrm{gos}$ , 211va, 211comp, 211txpixsub , 211gos , 212va , 212comp, 212txpixsub , 212gos ,213va , 213comp, 213txpixsub, 213gos , 22va, 22comp, 22txpixsub , 22gos , 23va , 23comp, 23txpixsub, 23gos , 31gva , 31gcomp, 31gtxpixsub, 31ggos , 33dgva , 33dgcomp, 33dgtxpixsub , 33dggos , 321va , 321 comp, 321txpixsub , 321gos , 327va , 327comp , 327txpixsub , 327gos , 331va , 331 comp , 331txpixsub , 331gos , 332va , 332comp , 332txpixsub , 332gos , 333va , 333comp, 333txpixsub , 333gos , 334va , 334comp , 334txpixsub , 334gos , 335va , 335comp , 335txpixsub , 335gos , 3361mvva , 3361mvcomp, 3361mvtxpixsub, 3361mvgos , 3364otva , 3364otcomp, 3364ottxpixsub, 3364otgos , 337va, 337 comp , 337txpixsub , 337gos , 339va , 339comp, 339txpixsub , 339gos , 31ndva, 31ndcomp, 31ndtxpixsub , 31ndgos , $311 \mathrm{ftva}$, $311 \mathrm{ftcomp} \mathrm{,} 311 \mathrm{fttxpixsub,} 311 \mathrm{ftgos}$, 313ttva , 313ttcomp , 313tttxpixsub, 313ttgos, 315alva, 315alcomp, 315altxpixsub, 315algos , 322va, 322comp.

- (2021d): "Components of value added by industry, 1997-2016," Release date: December 22, 2021. https://apps.bea.gov/iTable/iTable.cfm?reqid=150\&step= 3\&isuri=1\&table_list=6\&series=q\&first_year=1997\&columns=i i\&scale= -9\&last_year=2016\&categories=gdpxind\&thetable=\&rows $=22 r$.

(2021e): "International transaction accounts, Table 1.1," Release date: September 21, 2021.

(2021f): "International transaction accounts, Table 2.1," Release date: September $28,2021$.

- (2021g): "National income and product accounts (NIPA)," Last revised: December 22, 2021.

- (2021h): "National income and product accounts, Table 6.5B," Last revised: July $30,2021$.

(2021i): "Value added by industry, 1997-2016," Release date: September 30, 2021. https://apps.bea.gov/iTable/iTable.cfm?reqid=150\&step= 
3\&isuri=1\&table_list=1\&series=a\&first_year=1997\&columns=ii\&scale= -9\&last_year=2016\&categories=gdpxind\&thetable=\&rows=22r.

(2022a): "BEA depreciation estimates," https://apps.bea.gov/national/pdf/ BEA_depreciation_rates.pdf, Accessed January 2022.

(2022b): "U.S. direct investment abroad, all all U.S. parent companies (data for 2009 and forward), value added (gross product)," https:// apps . bea.gov/iTable/iTable.cfm?reqid=2\&step=10\&isuri=1\&step1prompt1= 1\&step2prompt3=14\&step1prompt2=2\&step8prompt10a=94\&step4prompt5= 99\&step3prompt4=6\&step5prompt $6=1$, 2\&step7prompt $8=40,41,42,43,48,49$ ,52, 55, 56, 58, 60\&step8prompt9a=45, Accessed January 2022.

(2022c): "U.S. direct investment abroad, all majority-owned affiliates, compensation of employees," https://apps.bea.gov/iTable/iTable.cfm ?reqid=2\&step=10\&isuri=1\&step1prompt 1=1\&step2prompt3=13\&step1prompt $2=$ 2\&step8prompt10a=1\&step4prompt5=4\&step3prompt4=7\&step5prompt6=1 , 2\&step7prompt8=43\&step8prompt9a=2, Accessed January 2022.

(2022d): "U.S. direct investment abroad, all majority-owned affiliates, employment," https://apps.bea.gov/iTable/iTable.cfm?reqid=2\&step=10\&isuri= 1\&step1prompt 1=1\&step2prompt3=13\&step1prompt 2=2\&step8prompt10a= 1\&step4prompt5=10\&step3prompt4=8\&step5prompt6=1, 2\&step7prompt8= 43\&step8prompt9a=47, Accessed January 2022.

(2022e): "U.S. direct investment abroad, all majority-owned affiliates, net property, plans, and equipment," https://apps.bea.gov/iTable/ iTable.cfm?reqid=2\&step=10\&isuri=1\&step1prompt1=1\&step2prompt3= 13\&step1prompt2=2\&step8prompt 10a=1\&step4prompt5=10\&step3prompt4= 54\&step5prompt6=1, 2\&step7prompt8=43\&step8prompt9a=71, Accessed January 2022.

(2022f): "U.S. direct investment abroad, all majority-owned affiliates, total assets," https://apps.bea.gov/iTable/iTable.cfm?reqid=2\&step=10\&isuri= 1\&step1prompt 1=1\&step2prompt3=13\&step1prompt 2=2\&step8prompt10a= 1\&step4prompt5=10\&step3prompt4=1\&step5prompt6=1, 2\&step7prompt8= 43\&step8prompt9a=40, Accessed January 2022.

(2022g): "U.S. direct investment abroad, all majority-owned foreign affiliates (data for 2009 and forward),value added (gross product)," https:// apps . bea.gov/iTable/iTable. cfm?reqid=2\&step=10\&isuri=1\&step1prompt 1= 1\&step2prompt3=13\&step1prompt2=2\&step8prompt 10a=94\&step4prompt5= 99\&step3prompt4=6\&step5prompt6 $=1$, 2\&step7prompt $8=40,41,42,43,48,49$ 
,52, 55, 56 , 58, 60\&step8prompt9a=45, Accessed January 2022.

(2022h): "U.S. direct investment abroad, direct investment income without current-cost adjustment," https://apps.bea.gov/iTable/iTable.cfm ?reqid=2\&step=10\&isur $i=1 \&$ step 1 prompt $1=1 \&$ step 2 prompt $3=1 \&$ step 1 prompt $2=$ 1\&step8prompt 10a=1\&step4prompt5=10\&step3prompt $4=27 \&$ step5prompt6=1

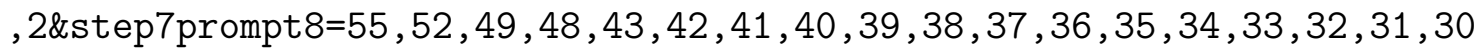
, 29, 28, 27 , 26 , 25 , 24, 23 , 22 , 21 , 20 , 19, 18, 17, 16 , 15 , 14 , 13\&step8prompt9a=2, Accessed January 2022.

(2022i): "U.S. direct investment abroad, direct investment income without current-cost adjustment," https://apps.bea.gov/iTable/iTable.cfm ?reqid=2\&step=10\&isuri=1\&step1prompt1=1\&step2prompt3=1\&step1prompt2= 1\&step8prompt 10a=1\&step4prompt5=10\&step3prompt4=27\&step5prompt6=1 , 2\&step7prompt8 $=55,52,49,48,43,42,41,40,39,38,37,36,35$, 34 , 33 , 32 , 31 , 30

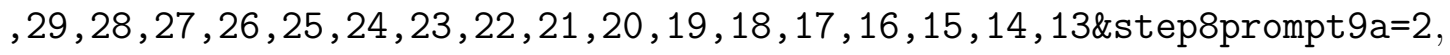
Accessed January 2022.

(2022j): "U.S. direct investment abroad, U.S. direct investment position abroad on a historical-cost basis," https://apps.bea.gov/iTable/iTable.cfm ?reqid=2\&step=10\&isuri=1\&step1prompt 1=1\&step2prompt3=1\&step1prompt $2=$ 1\&step8prompt 10a=1\&step4prompt5=10\&step3prompt4=30\&step5prompt6=1

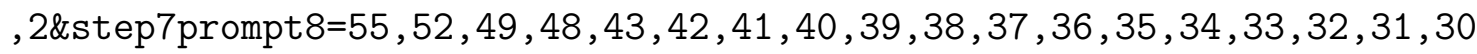
, 29, 28, 27, 26, 25 , 24, 23, 22, 21, 20, 19, 18, 17, 16, 15, 14 , 13\&step8prompt9a=2, Accessed January 2022.

Bureau of Labor Statistics (2021a): "Labor productivity and costs: Business and Nonfarm Business Sectors - November 4, 2021," Accessed January 2022.

(2021b): "Labor productivity and costs database: Industry productivity," Accessed January 2022.

(2022): "Major sector productivity and costs: Hours worked, business sector, PRS84006033," Accessed January 2022.

Byrne, D. M., J. G. Fernald, And M. B. Reinsdorf (2016): "Does the United States have a productivity slowdown or a measurement problem?," Brookings Papers on Economic Activity, Spring, 109-157.

Clausing, K. A. (2016): "The effect of profit shifting on the corporate tax base in the United States and beyond," National Tax Journal, 69(4), 905-934.

(2020): "How big is profit shifting," mimeo.

Cooper, M., J. McClelland, J. Pearce, R. Prisinzano, J. Sullivan, D. Yagan, O. ZidAR, AND E. ZWICK (2016): "Business in the united states: who owns it and 
how much tax do they pay?," Tax Policy and the Economy, 30(1), 91-128.

Curcuru, S. E., C. P. Thomas, and F. E. Warnock (2013): "On returns differentials," Journal of International Money and Finance, 36, 1-25.

Decker, R., J. Haltiwanger, R. Jarmin, and J. Miranda (2016): "Declining Business Dynamism: Implications for Productivity," Hutchins Center, Working Paper 23, Brookings Institution.

Dharmapala, D. (2014): "What do we know about base erosion and profit shifting? A review of the empirical literature," Fiscal Studies, 35(4), 421-448.

Elsby, M. W. L., B. Hobijn, and A. Sahin (2013): "The decline of the U.S. labor share," Brookings Papers on Economic Activity, Fall, 1-63.

Eurostat (2016): "Irish GDP revision," cso.ie/en/media/csoie/newsevents/ documents/EurostatIrishGDPcommunication.pdf.

Federal Reserve Bank of St. Louis (2022): "Spot crude oil price: West Texas Intermediate [WTISPLC]," https://fred.stlouisfed.org/series/WTISPLC, Accessed January 2022.

Fernald, J. G. (2015): "Productivity and potential output before, during, and after the Great Recession," in NBER Macroeconomics Annual 2014, ed. by J. A. Parker, and M. Woodford, vol. 29, pp. 1-51. University of Chicago Press.

Foley, C. F., J. C. Hartzell, S. Titman, and G. Twite (2007): "Why do firms hold so much cash? A tax based explanation," Journal of Financial Economics, 86(3), 579-607.

Fuest, C., T. Hemmelgarn, and F. Ramb (2007): "How would the introduction of an E.U.-wide formula apportionment affect the distribution and size of the corporate tax base? An analysis based on German multinationals," International Tax and Public Finance, 14(5), 605-626.

Garga, V., And S. R. Singh (2020): "Output Hysteresis and Optimal Monetary Policy," Journal of Monetary Economics, In press.

Gourinchas, P.-O., And H. Rey (2007): "From World Banker to World Venture Capitalist: US External Adjustment and the Exorbitant Privilege," in G-7 Current Account Imbalances: Sustainability and Adjustment, ed. by R. Clarida, pp. 11-55, Chicago,. University of Chicago Press,.

Grubert, H., And J. Mutti (1991): "Taxes, tariffs and transfer pricing in multinational corporate decision making," Review of Economics and Statistics, 73(2), 285-293.

Hausmann, R., and F. Sturzenegger (2007): "The missing dark matter in the wealth of nations and its implications for global imbalances," Economic policy, 22(51), 470518. 
Hines, JR, J. R., And E. M. Rice (1994): "Fiscal paradise: foreign tax havens and American business," Quarterly Journal of Economics, 109(1), 149-182.

International MONETARy Fund (2009): Balance of payments and international investment position manual. International Monetary Fund, Washington, D.C., 6 edn.

Karabarbounis, L., And B. Neiman (2014): "The global decline of the labor share," Quarterly Journal of Economics, 129(1), 61-103.

LIPSEY, R. E. (2009): "Measuring international trade in services," in International Trade in Services and Intangibles in the Era of Globalization, ed. by M. Reinsdorf, and M. J. Slaughter, pp. 27-74. University of Chicago Press.

- (2010): "Measuring the location of production in a world of intangible productive assets, FDI, and intrafirm trade," Review of Income and Wealth, 56(1), S99-S110.

McGrattan, E. R., and E. C. Prescott (2010): "Technology capital and the U.S. current account," American Economic Review, 100(4), 1493-1522.

Moulton, B. R. (2018): "The measurement of output, prices, and productivity: What's changed since the Boskin Commission?," The Brookings Institution Hutchins Center on Fiscal and Monetary Policy.

Moylan, C. E., And C. A. Robbins (2007): "Research and Development Satellite Account Update," Survey of Current Business, 87(10), 49-64.

RAssier, D. G. (2014): "Formulary measures for the U.S. current account: accounting for transactions attributable to special purpose entities of multinational enterprises," Journal of Economic and Social Measurement, 39(4), 257-281.

(2017): "Improving the SNA treatment of multinational enterprises," Review of Income and Wealth, pp. S287-S320.

Rassier, D. G., AND J. KonCz-Bruner (2015): "A formulary approach for attributing measured production to foreign affiliates of U.S. parents," in Measuring Globalization: Better Trade Statistics for Better Policy, ed. by S. N. Houseman, and M. J. Mandel, pp. 229-262. W.E. Upjohn Institute for Employment Research.

Runkel, M., And G. Schjelderup (2011): "The choice of apportionment factors under formula apportionment," International Economic Review, 52(3), 913-934.

SAnCHIRICO, C. W. (2015): "As American as Apple Inc.: international tax and ownership nationality," Tax Law Review, 68(2), 207-274.

Senate Committee on Homeland Security and Government Affairs (2013): "Offshore Profit Shifting and the U.S. Tax Code: Hearings before the Committee on Homeland Security and Government Affairs, 113th Cong.," Testimony of Stephen Shay, September 20.

Smyth, J. (2017): "Chevron settles landmark Australia case on transfer pricing," Financial 
Times, August 18.

Sullivan And Cromwell, LLP (2011): "Transfer pricing developments - cost sharing arrangements," December 28.

Syverson, C. (2017): "Challenges to mismeasurement explanations for the U.S. productivity slowdown," Journal of Economic Perspectives, 31(2), 165-86.

Torslov, T., L. Wier, And G. Zucman (2020): "The missing profits of nations," mimeo.

United Nations (2015): Guide to Measuring Global Production. United Nations.

United Nations, Eurostat, and Organisation for Economic Co-operation And Development (2011): The Impact of Globalization on National Accounts. United Nations.

U.S. Department of the Treasury (2007): "Report to the Congress on Earnings Stripping, Transfer Pricing, and US Income Tax Treaties," November.

Wright, T., And G. ZuCMAn (2018): "The exorbitant tax privilege," NBER Working paper 24983. 